\title{
A CATALOGUE OF DOSEMETERS AND DOSIMETRIC SERVICES WITHIN EUROPE-AN UPDATE
}

\author{
M. A. Lopez Ponte ${ }^{1}$, C. M. Castellani ${ }^{2}$, L. Currivan ${ }^{3}$, J. W. E. VanDijk ${ }^{4}$, R. Falk ${ }^{5}$, P. Olko ${ }^{6, *}$ and C. Wernli ${ }^{7}$ \\ ${ }^{1}$ CIEMAT-Dosimetry Unit, Avda. Complutense 22, 28040 Madrid, Spain \\ ${ }^{2}$ ENEA-IRP, 40136 Bologna, Italy \\ ${ }^{3}$ RPII, Dublin 14, Ireland \\ ${ }^{4}$ NRG Radiation and Environment, Utrechtseweg 310, Postbus 9034, 6800 AS Arnhem, Netherlands \\ ${ }^{5}$ SSI, Stockholm, Sweden \\ ${ }^{6}$ Institute of Nuclear Physics, Radzikowskiego 152, PL 31-342 Krakow, Poland \\ ${ }^{7}$ Paul Scherrer Institute, CH-5232 Villigen PSI, Switzerland
}

\begin{abstract}
The catalogue of dosemeters and dosimetric services within the European Union (EU) Member States and Switzerland that was issued by EURADOS in the year 2000 has been updated and extended with information on dosimetric services in the new EU Member States and Bulgaria, Croatia, Romania, Serbia and Montenegro, and Ukraine. The total number of dosimetric services in these European countries is now estimated to be about 200. The present catalogue is based on information collected from 90 European dosimetric services, among which 34 questionnaires from 32 services were obtained over the years 2001-2004 for the first time. This article assesses and updates the present use of personal dosemeters and the extent to which occupationally exposed persons in Europe are monitored with dosemeters able to measure the operational quantitypersonal dose equivalent, $H_{\mathrm{P}}(d)$. The perspective of joining $\mathrm{EU}$ by the new countries accelerated the implementation of the EU Basic Safety Standard Directive to their national regulations. As a result, all newly investigated services reported their ability to measure $H_{\mathrm{P}}(d)$. The catalogue provides information on the dosemeters, dose calculation and background subtraction algorithms, calibration methods, energy and angular response, and performance.
\end{abstract}

\section{INTRODUCTION}

In the year 2000, an overview of dosemeters and dosimetric services within the European Union (EU) Member States and Switzerland, where external radiation doses were estimated in the form of personal dose equivalent, $H_{\mathrm{P}}(d)$, was prepared by the EURADOS working group and published in a special issue of Radiation Protection Dosimetry ${ }^{(1)}$. Information for the compilation of that report was obtained from questionnaires sent to dosimetric services. In the report it was estimated that roughly $50 \%$ of the occupationally exposed persons in the EU and Switzerland were at that time monitored in terms of personal dose equivalent, $H_{\mathrm{P}}(10)$ and $H_{\mathrm{P}}(0.07)$. Over the years 2001-2004 a slightly modified EURADOS questionnaire was distributed among dosimetric services in the EU candidate countries (Czech Republic, Estonia, Hungary, Latvia, Lithuania, Poland, Slovakia and Slovenia), and other European countries (Bulgaria, Romania, Ukraine, Croatia, Serbia and Montenegro). In addition, some services from Italy, Greece and Germany supplied updates of their data. The aim of this article is to assess and update information on the present use of personal dosemeters and their design. The perspective of joining EU by the new countries accelerated the implementation of the EU Basic Safety Standard Directive ${ }^{(2)}$ to their national regulations.

${ }^{*}$ Corresponding author: pawel.olko@ifj.edu.pl
As a result, all newly investigated services reported that they were able to measure $H_{\mathrm{P}}(d)$. The present catalogue is based on information collected from 90 European dosimetric services, among which 34 questionnaires from 32 services were obtained over the years 2001-2004 for the first time. The list of dosimetric services that responded to the questionnaire is given in the Appendix.

The discussion on the properties of the dosimetric systems and the dosemeters design does not imply any comparison of the quality of the systems. Therefore, in this article, the dosimetric performance of the services listed is presented in anonymous form to avoid any comparison between particular dosimetric services.

The present catalogue is essentially based on the report issued by the EURADOS working group in 2000 and is structured into the following sections:

- General information on European dosimetric services

- Dosemeter design

- Photon dose calculation and background subtraction algorithms

- Energy and angle dependence of response

- Calibration sources

- Performance

The amount of information collected from the questionnaires cannot be fully presented in this article due to the lack of space. Therefore, the full text of the report, including tables in Annexes, is available on the EURADOS web page www.eurados.org. 


\section{A. LOPEZ PONTE ET AL.}

GENERAL INFORMATION ON EUROPEAN DOSIMETRIC SERVICES

The EURADOS questionnaire distributed in 2002-2003, named the "EURADOS 2002 Questionnaire for a catalogue of dosemeters used for individual monitoring in European Countries" is in fact a copy of the questionnaire distributed in 1997-1998. Only the front page specifying the contact persons, return addresses and instructions were modified. The 14-page questionnaire consisted of seven sections that included information on the name and relevant addresses of the service; make, type and principles of dosemeters and the dosimetric system; dose calculation and background subtraction algorithms; type-testing methods, energy and angular response, calibration and Quality Assurance programmes. A copy of the questionnaire distributed in the years 2001-2004 is available in Annex I at www.eurados.org.

In the first round (1997-1999), each EURADOS action group member received a number of copies of the questionnaire and distributed them to services in his or her Member State. At that time, a total of 56 dosimetric services from 15 EU countries and Switzerland responded to the questionnaire. The dosimetric services that responded in the first run monitored about 615,000 occupationally exposed approximately one-half of the population of radiation workers in these countries. Within this population, 450,000 workers were monitored in terms of $H_{\mathrm{P}}(d)$. The difference was due to services in Austria and Germany, which did not monitor in terms of $H_{\mathrm{P}}(d)$ but reported 'Photonen-Äquivalentdosis' $\left(H_{X}\right)$, and in Italy, where dosimetric services reported kerma free-in-air values. In 2004, the legal quantity in Austria is represented by $H_{\mathrm{P}}(d)$ but due to the lack of the corresponding ordinance, most services were still using the old units.

In the second run, in the years 2001-2004, members of the EURADOS Working Group 2 and volunteers agreed to distribute the questionnaires to services in their countries. The list of the country coordinators is given in Table 1 . The present catalogue is based on information collected from 90 European dosimetric services, among which 34 questionnaires were obtained for the first time in 2001-2004, and 12 services from Germany, Italy and Greece who updated their questionnaires. The questionnaire was available as an MS-Word file or in a printed form. Four participants returned their questionnaires in hard copy, all others in electronic form, by e-mail.

In the first run (1997-1999) over 30 services supplied detailed information on the characteristics of their dosimetric systems, including energy and angular response. In the second run, most of the services provided rather limited sets of data, often with scant
Table 1. List of country coordinators, who distributed and collected EURADOS ${ }^{(1)}$ questionnaires.

\begin{tabular}{ll} 
Bulgaria & Metody Guelev \\
Croatia & Maria Ragonajec \\
Czech Republic & Karla Petrova \\
Estonia & Toomas Koop \\
Hungary & Marika Osvay \\
Latvia & Constantin Boguciarskis \\
Lithuania & Gendrutis Morkunas \\
Poland & Pawel Olko \\
Romania & Constantin Milu \\
Serbia and Montenegro & Mirjana Prokic \\
Slovakia & Denisa Nikodemova \\
Slovenia & Helena Janzejovic \\
Ukraine & Vadim Chumak \\
\hline
\end{tabular}

detail on the dosimetric characteristics. However, even this limited information was extremely useful in reviewing and cataloguing the personal dosimetric systems used in European countries.

In Table 2, the data are presented on the number of dosimetric services and monitored workers, who responded to the EURADOS questionnaire in 1997-1999 (columns 3 and 4), the number of services that reported in 1997-1999 their ability to assess $H_{\mathrm{P}}(d)$ and the number of workers who were monitored previously (columns 5 and 6) and in 2001-2004 (columns 7 and 8). In 1997-1999 most of the missing data were from a large number of Italian dosimetric services that did not measure $H_{\mathrm{P}}(d)$ but kerma free-in-air. In the updated questionnaires sent in the year 2002 the Italian services reported their results in terms of $H_{\mathrm{P}}(d)$. The data does not include workers monitored for neutron exposures. The number of services and monitored persons given in this report are an attempt to reflect the status between 1999 and the end of 2003. The information on the number of monitored persons was assessed from the average number of dosemeters processed per month because some services issue their dosemeters not only every month but also over 2-month or 3-month periods.

It was estimated in $2000^{(1)}$ that, based on the data provided by the responding dosimetric services, approximately half of the occupationally exposed persons of the EU and Switzerland were monitored by services that assessed the dose in terms of $H_{\mathrm{P}}(10)$ and $H_{\mathrm{P}}(0.07)$. The present set of data indicates that the services in the new Member States, which entered the EU in 2004, and in many other European countries almost exclusively monitor their workers in terms of personal dose equivalent.

General information on the dosimetric services and type of dosemeters, listed by country, is given in Table 3. The countries are given in alphabetical order of their EU country codes. 
CATALOGUE OF DOSIMETRIC SERVICES WITHIN EUROPE

Table 2. Data on the number of dosimetric services and monitored workers, who responded to the EURADOS questionnaire in 1997-1998 and 2002-2003.

\begin{tabular}{|c|c|c|c|c|c|c|c|}
\hline \multirow{3}{*}{$\begin{array}{l}\text { Country } \\
\text { code }\end{array}$} & \multirow{3}{*}{$\begin{array}{c}\text { EU } \\
\text { country } \\
\text { in } 2004\end{array}$} & \multicolumn{4}{|c|}{ EURADOS 1997-1998 } & \multirow{2}{*}{\multicolumn{2}{|c|}{$\begin{array}{c}\text { EURADOS 2002-2003, } \\
\text { Hp only }\end{array}$}} \\
\hline & & \multicolumn{2}{|c|}{ Total } & \multicolumn{2}{|c|}{$\mathrm{H}_{\mathrm{p}}(\mathrm{d})$ only } & & \\
\hline & & Services & Workers & Services & Workers & Services & Workers \\
\hline A & Yes & 4 & 33500 & - & - & - & - \\
\hline B & Yes & 3 & 6000 & 3 & 6000 & 3 & 6000 \\
\hline BG & No & & & & & 5 & 12450 \\
\hline $\mathrm{CH}$ & No & 10 & 62000 & 7 & 44900 & 7 & 44900 \\
\hline $\mathrm{CZ}$ & Yes & & & & & 4 & 20420 \\
\hline D & Yes & 8 & 52900 & - & - & - & - \\
\hline DK & Yes & 4 & 11000 & 3 & 11000 & 3 & 5350 \\
\hline E & Yes & 4 & 52800 & 4 & 52800 & 4 & 52800 \\
\hline EL & Yes & 3 & 5350 & 2 & 5350 & 1 & 8000 \\
\hline EST & Yes & & & & & 1 & 1050 \\
\hline $\mathrm{F}$ & Yes & 7 & 224900 & 7 & 224900 & 6 & 224900 \\
\hline FIN & Yes & 2 & 3400 & 2 & 3400 & 2 & 3400 \\
\hline $\mathrm{H}$ & Yes & & & & & 2 & 30000 \\
\hline HR & No & & & & & 2 & 3700 \\
\hline I & Yes & 2 & 8000 & - & - & 12 & 44170 \\
\hline IRL & Yes & 1 & 4500 & 1 & 4500 & 1 & 4500 \\
\hline $\mathrm{L}$ & Yes & 1 & 1100 & 1 & 1100 & 1 & 1100 \\
\hline LT & Yes & & & & & 2 & 4850 \\
\hline LV & Yes & & & & & 1 & 400 \\
\hline NL & Yes & 4 & 32600 & 4 & 32600 & 4 & 32600 \\
\hline PL & Yes & & & & & 3 & 35000 \\
\hline $\mathrm{P}$ & Yes & 1 & 4000 & 1 & 4000 & 1 & 4000 \\
\hline RO & No & & & & & 6 & 13350 \\
\hline S & Yes & 3 & 13300 & 3 & 13300 & 3 & 13300 \\
\hline SI & Yes & & & & & 2 & 3150 \\
\hline SK & Yes & & & & & 1 & 3700 \\
\hline UA & No & & & & & 2 & 2100 \\
\hline UK & Yes & 7 & 46900 & 7 & 46900 & 7 & 46900 \\
\hline YU & No & & & & & 2 & 5100 \\
\hline Total & 29 & 62 & 562250 & 48 & 450750 & 89 & 627190 \\
\hline
\end{tabular}

The data does not include workers monitored for neutrons.

\section{DOSEMETER DESIGN}

An ideal dosemeter should provide a reading proportional to dose (dose equivalent) to tissue at the given depth, independently of the radiation energy. A typical dosemeter used in individual monitoring consists of a detector placed in a holder. The holder protects the detector from disturbing environmental factors, corrects the energy and angular response and assures response at an appropriate depth. Therefore, the design of dosemeters has to take into account mainly the energy response, thickness and physical shape of the detector(s) and the composition, thickness and shape of the filters applied. The design of the holder has also taken into account the fact that the calibration is performed on the phantom, to consider the radiation backscatter from the body.
This article provides an overview of individual dosemeters used by dosimetric services in Europe. A catalogue is provided of the detectors applied (film, TLD) and different filters used in the dosemeters of the services, which responded to the questionnaires.

\section{Photon and beta + photon dosemeters}

\section{Principles of dosemeter design}

One of the requirements concerning detectors is their tissue equivalence, i.e. that their atomic composition should provide similar interaction of radiation to that with human tissue. The detector is considered to be tissue-equivalent if the ratio of its reading to the value of dose to tissue is independent of photon energy. The atomic composition of a material with 
Table 3. List of dosimetric services, with number of services applying given type of dosemeters and number of personnel under control.

\begin{tabular}{lllllllllllll}
\hline $\begin{array}{l}\text { Country } \\
\text { Code }\end{array}$ & PF & PT & PV & BF & BT & BV & NA & NH & NS & NM Various \\
\hline
\end{tabular}

A Number of services

Number of workers

Comments

$\begin{array}{cl}\text { B } & \begin{array}{l}\text { Number of services } \\ \text { Number of workers }\end{array} \\ \text { BG } & \begin{array}{l}\text { Number of services } \\ \text { Number of workers } \\ \text { Comments }\end{array} \\ \text { CH } & \begin{array}{l}\text { Number of services } \\ \text { Number of workers } \\ \text { CZ }\end{array} \\ \text { Comments } \\ \text { Number of services } \\ \text { Number of workers } \\ \text { Comment } \\ \text { Number of services } \\ \text { Number of workers } \\ \text { Comments }\end{array}$

DK Number of services

Number of workers

E Number of services

Number of workers

EL Number of services

Number of workers

EST Number of services

Number of workers

Comments

F Number of services

Number of workers

Comments

FIN Number of services

Number of workers

$\mathrm{H} \quad$ Number of services

Number of workers

HR Number of services

Number of workers

I Number of services

Number of workers

IRL Number of services

Number of workers

L Number of services

Number of workers

LT Number of services

Number of workers

LV Number of services

Number of workers

NL Number of services

Number of workers

PL Number of services

Number of workers

Comments

P Number of services

Number of workers
4

All four dosimetric services in Austria issue TLDs that assess the dose quantity 'Photonen Äquivalentdosis' $H_{x}$. ARCS starts to measure personal dose equivalent, $H_{\mathrm{P}}(10)$ in 2004

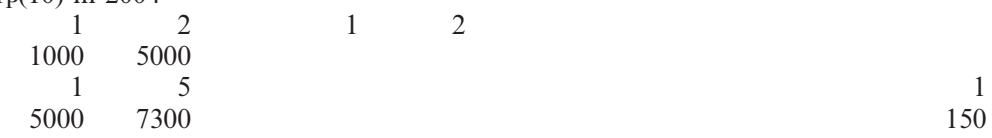

Various-electronic dosemeters. The monitoring periods are 1 month and 3 months

$\begin{array}{rrrrrrr}1 & 9 & 1 & 6 & 1 & 1 & 1 \\ 6000 & 56000 & 6000 & 54000 & 4000 & 1000 & 20\end{array}$

Various - direct storage device

$\begin{array}{rrrr}2 & 2 & 2 & 2 \\ 16,700 & 1650 & 2070 & 95\end{array}$

PV-AlP glas dosemeters

$\begin{array}{rrr}1 & 3 & 2 \\ 35000 & 9500 & \end{array}$

All dosimetric services assess the dose quantity 'Photonen Äquivalentdosis' $H_{x}$.

However, one dosimetric service uses a film dosemeter designed to measure personal dose equivalent, both $H_{\mathrm{P}}(10)$ and $H_{x}$. The dosimetric systems based on glass dosemeters are also capable of assessing both $H_{\mathrm{P}}(10)$ and $H_{x}$.

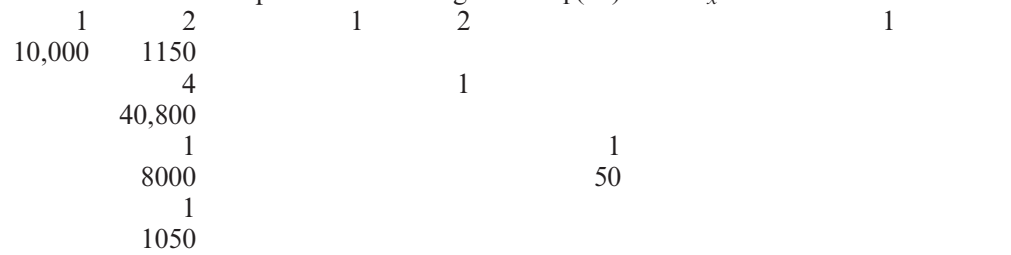

Monitoring periods are 1, 3, 6 months. Average number of dosemeters per month: 400

\begin{tabular}{|c|c|}
\hline $\begin{array}{ll}6 & 2\end{array}$ & 2 \\
\hline & 11 \\
\hline
\end{tabular}

The albedo dosemeters are used in combination with film dosemeters in multi-element type- 1 or type- 2 dosemeters

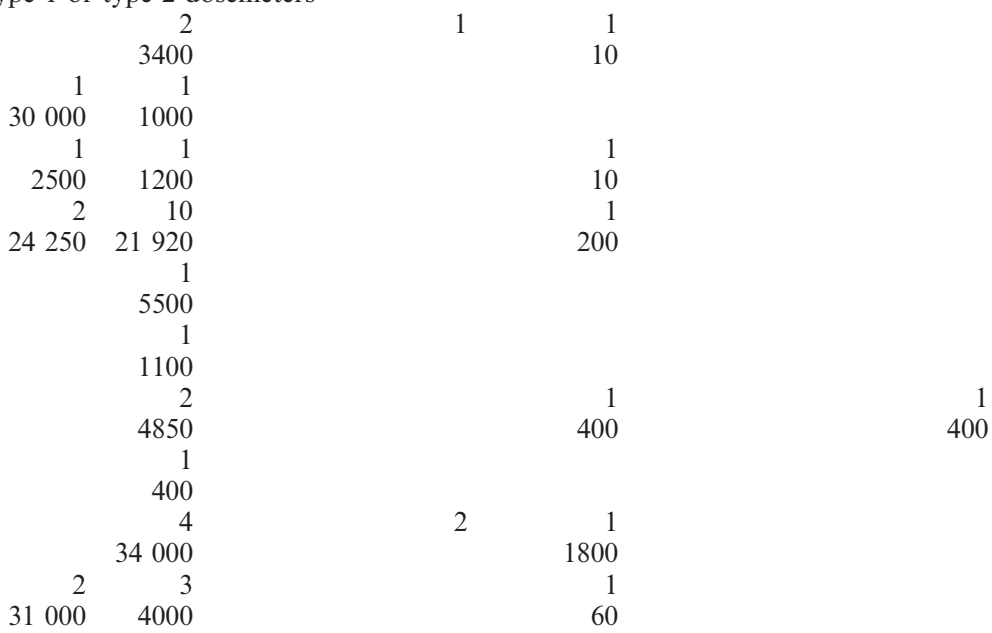

Monitoring periods are 1, 2, 3 and 4 months

4000 
Table 3. Continued

\begin{tabular}{|c|c|c|c|c|c|c|c|c|c|c|c|c|}
\hline $\begin{array}{l}\text { Country } \\
\text { Code }\end{array}$ & & $\mathrm{PF}$ & PT & PV & $\mathrm{BF}$ & BT & BV & NA & $\mathrm{NH}$ & NS & NM & Various \\
\hline \multirow[t]{2}{*}{$\mathrm{RO}$} & Number of services & 4 & 2 & & 1 & & & & & & & \\
\hline & Number of workers & 11650 & 1700 & & & & & & & & & \\
\hline \multirow[t]{2}{*}{ S } & Number of services & 1 & 1 & & & 1 & & 1 & & & & \\
\hline & Number of workers & 10000 & 3300 & & & 300 & & 3000 & & & & \\
\hline \multirow[t]{2}{*}{ SI } & Number of services & & 2 & & & & & 1 & & & & 1 \\
\hline & Number of workers & & 3150 & & & & & 6 & & & & \\
\hline \multirow[t]{3}{*}{ SK } & Number of services & 1 & 1 & & & & & 1 & & & & \\
\hline & Number of workers & & 3700 & & & & & 20 & & & & \\
\hline & Comments & $\begin{array}{l}\text { Film dos } \\
\text { Czech Re }\end{array}$ & imetry is & rform & d by & Nationa & Radi & tion $\operatorname{Pr}$ & ection & Servic & in the & \\
\hline \multirow[t]{2}{*}{ UA } & Number of services & & 2 & & & & & & & & & \\
\hline & Number of workers & & 2100 & & & & & & & & & \\
\hline \multirow[t]{2}{*}{ UK } & Number of services & 5 & 2 & & & & & & & 3 & & \\
\hline & Number of workers & 47000 & 21000 & & & & & & & & & \\
\hline \multirow[t]{2}{*}{ YU } & Number of services & & 2 & & & & & & & & & \\
\hline & Number of workers & & 5100 & & & & & & & & & \\
\hline
\end{tabular}

The following categories of dosemeters are specified: photon whole-body dosemeters (PF: photographic film, PT: thermoluminescent, PV: various (glass, electronic, OSL), beta whole-body dosemeters (BF: photographic film, BT: thermoluminescent, BV: various (electronic, OSL), neutron whole-body dosemeters (NA: albedo, NH: high energy, NS: Multi-element type 1 (one detector type and different converters), NM: Multi-element type 2 (different detector types)).

Table 4. Effective atomic number, with regard to $X$ rays, for different TLDs.

\begin{tabular}{lc}
\hline Detector & $Z_{\text {eff }}$ \\
\hline $\mathrm{LiF}$ & 8.3 \\
$\mathrm{CaF}_{2}$ & 16.3 \\
$\mathrm{Li}_{2} \mathrm{~B}_{4} \mathrm{O}_{7}$ & 7.35 \\
$\mathrm{Al}_{2} \mathrm{O}_{3}$ & 11.3 \\
$\mathrm{CaSO}_{4}$ & 15.7 \\
\hline
\end{tabular}

respect to interaction with photons is frequently expressed in terms of effective atomic number $Z_{\text {eff }}$. A substance is considered tissue-equivalent with regard to interactions with photons if its $Z_{\text {eff }}$ is close to that of soft tissue, which in turn is equal to 7.4. In Table 4, the values of $Z_{\text {eff }}$ calculated are given for the most common thermoluminescent detectors. Since the ratio of tissue kerma to air kerma for photons in the energy range between $10 \mathrm{keV}$ and $10 \mathrm{MeV}$ is approximately constant, a dosemeter calibrated in terms of air kerma will give a good estimate of tissue dose, to within $10 \%{ }^{(3)}$. It should be noted that radiation fields used in radiation protection for calibration of personal dosemeters are typically characterised in terms of air kerma but the properties of dosemeters (detectors and filters) should determine the ability of personal dosemeters to follow the legal dosimetric quantity, $H_{\mathrm{P}}(d)$.

The photon energy response of a detector is calculated as the ratio of the detector signal measured for the given type of radiation and energy, to the signal obtained after irradiation of the detector with the same dose in tissue (or kerma in air) of reference radiation, e.g. ${ }^{137} \mathrm{Cs}-$ gamma rays. To the first approximation the photon energy response of the detector depends on the material composition, which determines the cross sections for photon interaction within the detector, as compared to tissue (air). Therefore, the energy response of the given detector is frequently estimated as the ratio of dose in the detector material to that in tissue (air). In Figure 1 the ratio of mass energy absorption coefficients of $\mathrm{LiF}$ and air, and $\mathrm{Li}_{2} \mathrm{~B}_{4} \mathrm{O}_{7}$ and air (solid lines) are plotted against the measured response of $\mathrm{LiF}: \mathrm{Mg}, \mathrm{Ti}$ (MTS-N), $\mathrm{LiF}: \mathrm{Mg}, \mathrm{Cu}, \mathrm{P}$ $(\mathrm{MCP}-\mathrm{N})$ and $\mathrm{Li}_{2} \mathrm{~B}_{4} \mathrm{O}_{7}: \mathrm{Cu}$ detectors. The measured energy response of MTS-N is approximately $10 \%$ higher due to the variation of thermoluminescence efficiency for conversion of deposited energy into TL light (LET effect). This phenomenon is quite pronounced for $\mathrm{LiF}: \mathrm{Mg}, \mathrm{Cu}, \mathrm{P}$ detectors and for aluminium oxide detectors, $\mathrm{Al}_{2} \mathrm{O}_{3}: \mathrm{C}$, where the ratio between the calculated and measured response reaches 1.25 for $100 \mathrm{keV}$ photons. Therefore, for the design of dosemeters one should apply only the experimentally determined detector energy response.

The over-response of dosemeters can be compensated for by the use of appropriate filters. The role of the filter is mainly to reduce the fluence of photons by taking advantage of absorption edges of materials with $Z$ higher than that of tissue elements. 


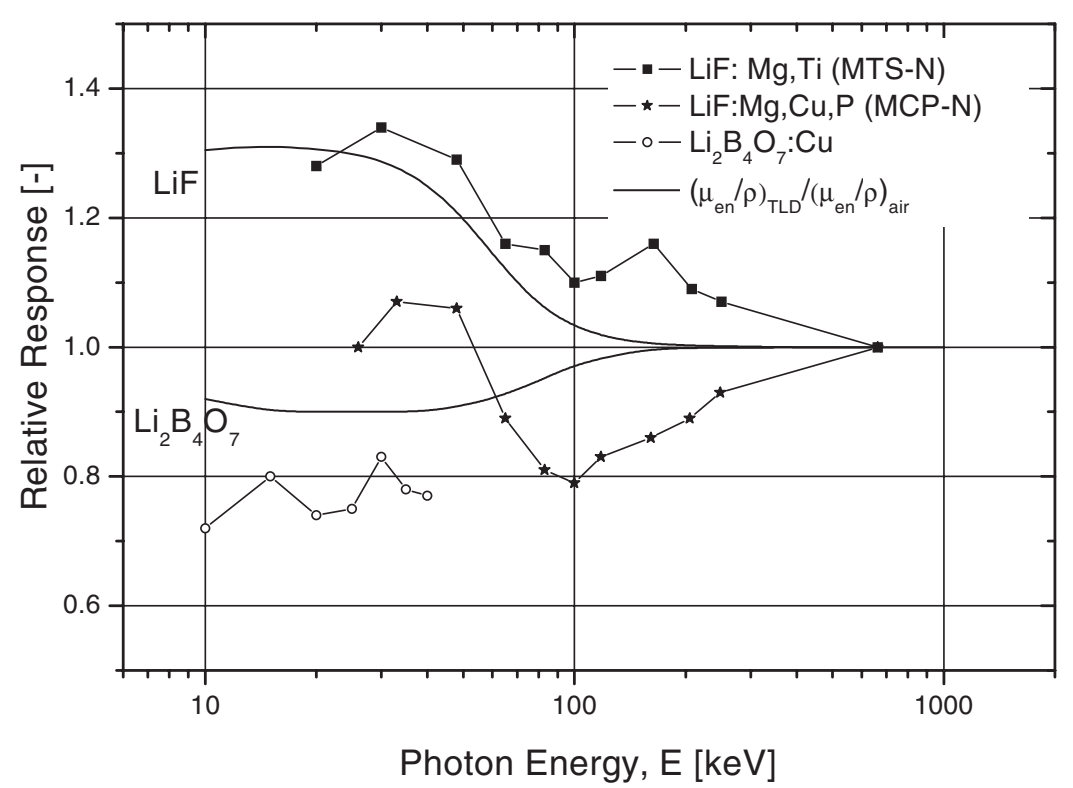

Figure 1. The ratio of measured response of LiF:Mg,Ti (MTS-N) (squares), LiF:Mg,Cu,P (MCP-N) (stars) and $\mathrm{Li}_{2} \mathrm{~B}_{4} \mathrm{O}_{7}: \mathrm{Cu}$ (circles) thermoluminescence detectors, normalised to kerma free-in-air, $K_{\text {air, }}$ as a function of photon energy. The solid lines represent the ratio of mass energy response coefficients of $\mathrm{LiF}$ to air and $\mathrm{Li}_{2} \mathrm{~B}_{4} \mathrm{O}_{7}$ to air.

A combination of filters can be optimised so that the dosemeter (with the given detector) will follow the required $H_{\mathrm{P}}(d)$ energy response. In film dosimetry, high over-response for $\mathrm{X}$ rays can be compensated for by using filters with a higher atomic number than that of the detector or by filtration analysis, i.e. by using more than one detector covered with different filters (or by screening one film with different filters). In this case the effective energy of incident radiation can be estimated from the ratio of responses under the different filters and a correction factor for the unscreened part of the film. In another approach, each part of the film is covered with a different filter and is regarded as an individual dosemeter. An example of the response of a dosemeter with four filters and an algorithm is presented in Figure 2.

\section{Dosemeters for photon or beta and photon dosimetry}

Whole-body dosemeters for photon or beta and photon dosimetry are divided below into three categories: film, thermoluminescence and 'various' (glass, electronic). The catalogue of different filters used in the film and the thermoluminescence dosemeters (TLDs) of the services that responded to the questionnaire, is presented in Annex II, in the full version of the report under www.eurados.org. This variety of dosemeter design reflects the broad range of dosemeters currently used in Europe. It should be pointed out that only about $30 \%$ services reported for those dosemeters the response characteristics, which were obtained mainly during type testing.

In Table 5 the list of dosimetric films, applied in European services, is presented. In the previous version of the EURADOS report, Agfa and Kodak films were reported to be exclusively applied by services in the 15 old EU countries. In five dosimetric services in the Czech Republic, Slovakia and Poland, FOMA dosimetric films (made in the Czech Republic) are applied for whole body photon and beta monitoring.

Table 6 lists the various TLD type thermoluminescent detectors applied. In the present catalogue lithium borate, calcium sulphate and calcium fluoride detectors are being applied in radiation monitoring, as compared to the previous specification of TLDs. No service reported routine application of the OSL technique and of the aluminium oxide detectors.

\section{Beta dosemeters}

The state of the design of beta dosemeters currently applied in European countries was presented in the previous EURADOS catalogue ${ }^{(1)}$, basing on dosemeters included in the beta dose performance tests. Beta dosemeters are typically available as whole-body dosemeters or extremity dosemeters (wrists, finger rings). The whole-body personal dosemeters have usually a dedicated detector (or a fragment of the dosimetric film) designed to measure $H_{\mathrm{P}}(0.07)$. The text below summarises the main 


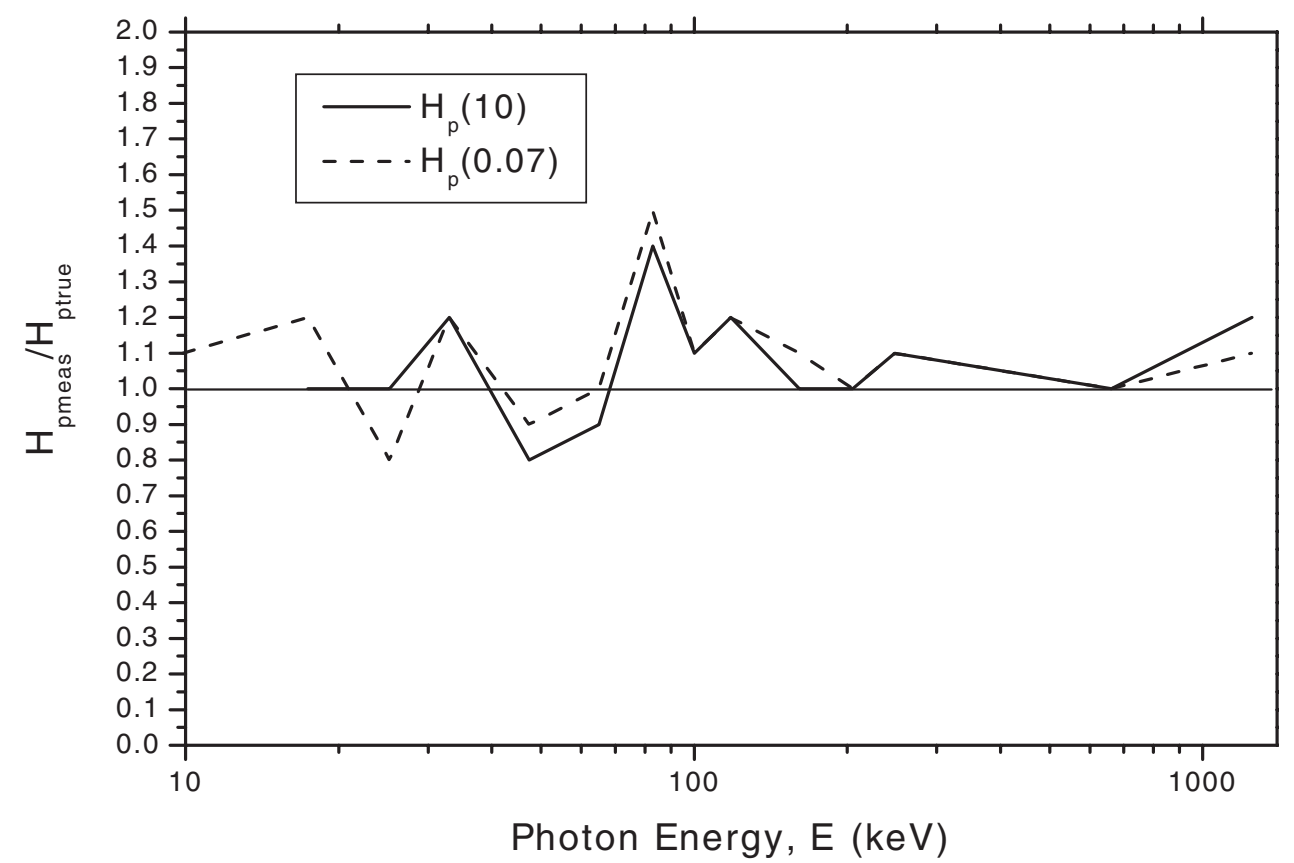

Figure 2. Response of a photographic film dosemeter with four filters and an algorithm for calculating dose from film densities.

Table 5. List of dosimetric films, applied in European dosimetric services for personal monitoring of photon and beta doses.

\begin{tabular}{ll}
\hline Producer & Type \\
\hline $\begin{array}{l}\text { Foma Bohemia Ltd (Cz) } \\
\text { Kodak (USA) }\end{array}$ & $\begin{array}{l}\text { Monitoring Film R10 }+ \text { R2 } \\
\text { Kodak Type II } \\
\text { Monitoring Film } \\
\text { Agfa (D) }\end{array}$ \\
\hline
\end{tabular}

properties of a beta dosemeter, which have to be taken into account in its design and type testing. These properties remain valid for whole body dosemeters, described in the previous section. For 61 TLD badges, presented in Annex II, only six had no thin filter/window for $H_{\mathrm{P}}(0.07)$ dosimetry.

Skin, extremities and the lens of the eye are the main organs at risk due to exposure to beta rays with energies below $2 \mathrm{MeV}$. For most beta-radiation fields, skin is the part of the extremity receiving the highest dose. Therefore, the dose limit for skin extremities is more likely to become the limiting organ than the extremity itself. The personal dose equivalent, $H_{\mathrm{P}}(d)$ for beta radiation fields is then determined at the depth $d=0.07 \mathrm{~mm}$ for skin dose assessment, $d=3 \mathrm{~mm}$ for dose to the eye lens and $d=10 \mathrm{~mm}$ for high energy (above $2 \mathrm{MeV}$ ) beta rays, e.g. for dose to the testes.
Table 6. The list of abbreviations and trade names for TLD materials used in European dosimetric services.

TLD-100

$\mathrm{LiF}: \mathrm{Mg}$, Ti natural Li isotopes from Thermo Electron (former Harshaw/Bicron NE) Both ${ }^{6} \mathrm{Li}$ and

${ }^{7} \mathrm{Li}$ are available as TLD-600 and

GR-200 TLD-700

$\mathrm{LiF}: \mathrm{Mg}, \mathrm{Cu}, \mathrm{P}$ natural $\mathrm{Li}$ isotopes from Beijing Shiying Radiation Detector Works, China. Both ${ }^{6} \mathrm{Li}$ and ${ }^{7} \mathrm{Li}$ are available as GR-206 and GR-2007

MCP-N LiF:Mg,Cu,P TLD Poland (former TLD Niewiadomski). Both ${ }^{6} \mathrm{Li}$ and ${ }^{7} \mathrm{Li}$ available as MCP-6 and MCP-7

MTS-N LiF:Mg,Ti TLD Poland (former TLD Niewiadomski). Both ${ }^{6} \mathrm{Li}$ and

$\mathrm{LiF}$

DTG-4

LiF:Mg, $\mathrm{Cu}, \mathrm{P}$

$\mathrm{Li}_{2} \mathrm{~B}_{4} \mathrm{O}_{7}: \mathrm{Mn}$

$\mathrm{Li}_{2} \mathrm{~B}_{4}^{11} \mathrm{O}_{7}: \mathrm{Cu}$

$\mathrm{Li}_{2} \mathrm{~B}_{4} \mathrm{O}_{7}: \mathrm{Cu}, \mathrm{Ag}, \mathrm{P}$

$\mathrm{MgB}_{4} \mathrm{O}_{7}$ : Dy, $\mathrm{Na}$

$\mathrm{CaSO}_{4}: \mathrm{Dy}$

$\mathrm{CaSO}_{4}: \mathrm{Tm}$

${ }^{7} \mathrm{Li}$ available as MTS-6 and MTS-7

LiF:Mg,Ti unspecified

LiF:Mg,Ti, Russian production

$\mathrm{LiF}: \mathrm{Mg}, \mathrm{Cu}, \mathrm{P}$ unspecified

$\mathrm{Li}_{2} \mathrm{~B}_{4} \mathrm{O}_{7}: \mathrm{Mn}, \mathrm{RADOS}$, Finland

Panasonic, Japan. Both ${ }^{n} \mathrm{Li}$ and

${ }^{7} \mathrm{Li}$ available

Vinca, Serbia and Montenegro

Vinca, Serbia and Montenegro

$\mathrm{CaSO}_{4}$ :Dy unspecific

Panasonic, Japan

$\mathrm{CaF}_{2}$ unspecific 


\section{A. LOPEZ PONTE ET AL.}

In designing a beta dosemeter with satisfactory energy and angle dependence of response for measurement of $H_{\mathrm{P}}(0.07)$ the following design parameters should be considered:

Thickness of the detector. If the thickness of the detector is higher than the range of beta rays, a skin dose correction factor may be applied to obtain the true $H_{\mathrm{P}}(0.07)$ value from the measured value ${ }^{(4)}$. This is possible if the monitored radiation field is known. For low-energy beta particles (e.g. for ${ }^{147} \mathrm{Pm}$ with average energy $60 \mathrm{keV}$ ) detectors with a thickness of about $5 \mathrm{mg} \mathrm{cm}^{2}$ are preferable and, in principle, do not require correction after calibration with standard ${ }^{137} \mathrm{Cs},{ }^{60} \mathrm{Co}$ or ${ }^{90} \mathrm{Y} /{ }^{90} \mathrm{Sr}$ sources ${ }^{(5)}$. A decreased effective thickness of the detector can be obtained for TL detectors after mixing the grains of sensitive material with graphite, to reduce the layer from which TL light escapes from the TL detector ${ }^{(5)}$.

Detector efficiency as a function of electron energy. The change of detection efficiency with electron energy must be taken into account in the new generation of high-sensitive phosphors ( $\mathrm{LiF}: \mathrm{Mg}, \mathrm{Cu}, \mathrm{P}, \mathrm{LiF}: \mathrm{Mg}, \mathrm{Na}$, $\mathrm{Al}_{2} \mathrm{O}_{3}: \mathrm{C}$ ). A decrease of detection efficiency in these phosphors with decreasing electron energy is an ionisation density (LET) effect. Due to this effect the detection efficiency for thin layer $\mathrm{LiF}: \mathrm{Mg}, \mathrm{Cu}, \mathrm{P}$ (MCP-Ns) detectors per unit absorbed dose for ${ }^{147} \mathrm{Pm}$ beta rays (relative to ${ }^{137} \mathrm{Cs}$ ) is only $0.90^{(6)}$.

Sensitivity of the detector. Over the last decade, high-sensitive detectors were introduced into practice, mainly $\mathrm{LiF}: \mathrm{Mg}, \mathrm{Cu}, \mathrm{P}$ and $\mathrm{Al}_{2} \mathrm{O}_{3}: \mathrm{C}$, which allow one to obtain the required measurement precision from a $5 \mathrm{mg} \mathrm{cm}^{2}$ detector layer after doses of $10 \mu \mathrm{Gy}$.
Thickness of the filter. A filter is applied to protect the detector against the harmful effects of the environment and to simulate the outermost layer of the skin, which is not sensitive to radiation. The optimum filter thickness is $7 \mathrm{mg} \mathrm{cm}^{-2}$ for a very thin detector. The filter thickness also strongly influences the angle dependence of the dosemeter.

Filter/detector geometry. The detector should be held as close as possible to the filter to minimise the shadow effect for beta rays entering the detector from large incident angles.

\section{Neutron dosemeters}

Neutron personal dosemeters are usually worn on the body trunk and are intended to determine personal dose equivalent, $H_{\mathrm{P}}(10)$. In Figure 3 the Monte Carlo-calculated conversion coefficients ${ }^{(8)}$ from neutron fluence to $H_{\mathrm{P}}(10)$ are shown for normal neutron incidence. Energy and angle response of an ideal neutron dosemeter should match as closely as possible this conversion coefficient, i.e. the ratio of measured response per unit fluence, $\Phi$ of neutrons with the given energy and the $H_{\mathrm{P}}(10) / \Phi$ conversion coefficient should be approximately constant over the considered range of neutron energy. In such a case a single calibration coefficient, universal for all beams, can be applied. This is typically not the case for personal neutron dosemeters, which are frequently calibrated for particular radiation fields.

The physics of neutron dosimetry is based on interactions of neutrons with nuclei producing charged secondaries that can be registered by appropriate detector systems ${ }^{(1)}$. For some isotopes

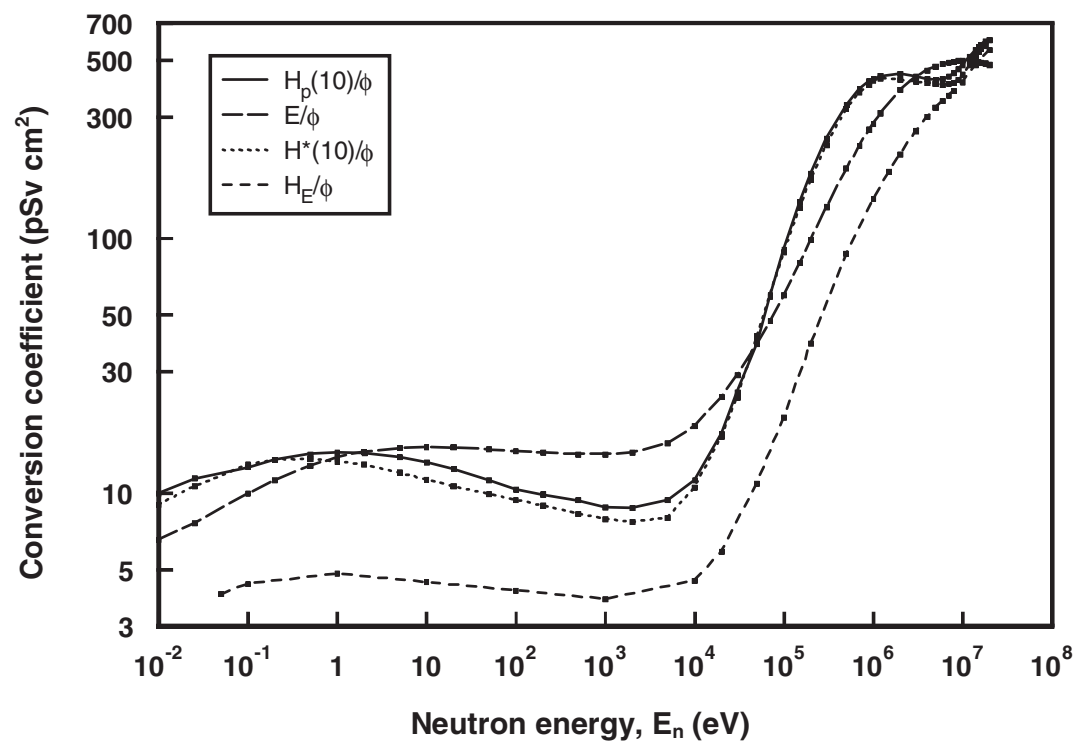

Figure 3. Conversion coefficients from neutron fluence to $H_{\mathrm{P}}(10), H^{*}(10), H_{\mathrm{E}}$ and $E$ from ICRU $57^{(7)}$. 
(e.g. ${ }^{10} \mathrm{~B},{ }^{6} \mathrm{Li},{ }^{113} \mathrm{Cd}$ ) very high cross sections for such nuclear reactions with thermal neutrons occur. Therefore, dosemeters based on the detection of neutrons thermalised in the body (albedo dosemeters) are relatively easy to build and are used most frequently. Commercially available albedo dosemeters typically use pairs of thermoluminescent detectors, one with ${ }^{6} \mathrm{Li}$, with a high cross section for the reaction $n\left({ }^{6} \mathrm{Li}, \alpha\right)^{3} \mathrm{H}$, and another with ${ }^{7} \mathrm{Li}$, sensitive predominantly to the $\gamma$-ray dose. The difference in the measured signals of those two detectors may be attributed to the neutron dose. However, albedo dosemeters show a pronounced dependence of the measured signal on the neutron spectrum, which decrease rapidly with increasing neutron energy and therefore require field calibration. No generalised energy dependence can be given since variations between systems are considerable, but albedo dosemeters are typically used for assessing doses from neutrons of energies not exceeding a few mega electron volt.

Technically more demanding, but still feasible, are systems to measure dose from fast neutrons in the energy range of $0.1-100 \mathrm{MeV}$. These systems are capable of detecting charged secondaries produced by high energy neutrons, mainly recoil protons and alpha particles. For neutrons of lower (except thermal) and higher energy, personal neutron dosimetry is extremely difficult. To overcome the problems of energy dependence, multi-element dosemeters sensitive to thermal and fast neutrons have been designed. Dose evaluations for unknown neutron spectra are then carried out using specific algorithms.

The available neutron dosemeters can be listed as albedo dosemeters, high energy dosemeters, and multi-element dosemeters. The last, third, category may be subdivided into dosemeters with one type of detector and different converters, and dosemeters with different types of detectors.

In this article the following abbreviations are used:

\begin{tabular}{ll} 
NA: & (Neutron) Albedo dosemeter \\
NH: & (Neutron) High energy dosemeter \\
NS: & (Neutron) Multi-element dosemeter, type 1 \\
NM: & $\begin{array}{l}\text { (Ne detector type and different converters) } \\
\text { (different detector types) }\end{array}$ \\
\hline
\end{tabular}

In Table 7, a list is given of the detectors and converter materials used in the neutron dosemeters in European dosimetric services, responded to the questionnaires.

Table 7. Types of neutron dosemeters in use at the dosimetric services in the European countries.

\begin{tabular}{|c|c|c|c|c|c|}
\hline $\begin{array}{l}\text { Country } \\
\text { code }\end{array}$ & $\begin{array}{l}\text { Service } \\
\text { code }\end{array}$ & $\begin{array}{l}\text { Dosemeter } \\
\text { type }\end{array}$ & Detector & Converter & $\begin{array}{l}\text { Dosemeter } \\
\text { per period }\end{array}$ \\
\hline B & SCK-CEN & NM & Bubble: BD-PND/BDT & & 15 \\
\hline $\mathrm{CH}$ & CERN & NS & PACD (CR-39) from 2005 & & 4000 \\
\hline $\mathrm{CH}$ & PSI & NS & PADC (CR39) & PE(Li), PE & 1000 \\
\hline $\mathrm{CZ}$ & Temelin NPP & NA & TLD (6LiF/7LiF) & & 35 \\
\hline $\mathrm{CZ}$ & Dukovany NPP & NA & TLD (6LiF/7LiF) & & 60 \\
\hline $\mathrm{CZ}$ & IRP & NS & Mylor foil & $\mathrm{U}, \mathrm{Th}$ & 400 \\
\hline $\mathrm{D}$ & FZK HS-M & NA & TLD (6LiF/7LiF) & & 1200 \\
\hline DK & RISO & NM & PADC (CR39)/TLD & Plastic & 75 \\
\hline EL & GAEC & NA & TLD (6LiF/7LiF) & & 60 \\
\hline EL & NPL & NS & PADC (CR39) & $6 \mathrm{LiF}, \mathrm{PE}$ & \\
\hline $\mathrm{F}$ & COGEMA & NS & TLD (6LiF/7LiF) & & 12,100 \\
\hline $\mathrm{F}$ & IRSN & NS & PADC (CR39) & & 2000 \\
\hline $\mathrm{F}$ & LCiE & NS & PADC (CR39) & & 1300 \\
\hline FIN & STUK & NA & TLD (6LiF/7LiF) & & 30 \\
\hline $\mathrm{H}$ & EPS & NA & TLD (6LiF/7LiF) & & 50 \\
\hline HR & RBI & NA & TLD $(6 \mathrm{LiF} / 7 \mathrm{LiF})$ & & 10 \\
\hline I & ENEA & NM & PADC (CR39)/TLD (7LiF/LiF) & & 800 \\
\hline LT & Ignalina NPP & NA & TLD $(6 \mathrm{LiF} / 7 \mathrm{LiF})$ & & 400 \\
\hline NL & $\mathrm{ECN}$ & NA & TLD $(6 \mathrm{LiF} / 7 \mathrm{LiF})$ & & 2200 \\
\hline PL & IFJ & NA & TLD $(6 \mathrm{LiF} / 7 \mathrm{LiF})$ & & 60 \\
\hline S & Ringhals & NA & TLD & & 3000 \\
\hline SI & Krsko NPP & NA & TLD (6LiF/7LiF) & & 6 \\
\hline SK & Bohunice NPP & NA & TLD (6LiF/7LiF) & & 20 \\
\hline UK & NRPB & NS & PADC (CR39) & & 600 \\
\hline UK & NRPB & NS & PADC (CR39) & Nylon & 1800 \\
\hline
\end{tabular}




\section{A. LOPEZ PONTE ET AL.}

\section{PHOTON DOSE CALCULATION AND BACKGROUND SUBTRACTION \\ ALGORITHMS}

To find the dose from the signal of the evaluating equipment, such as the output of a densitometer for measuring optical densities of a photographic film or the signal from the photomultiplier tube of a TLDreader, some calculations must be performed. For a single detector per measured quantity these calculations can be as simple as subtracting the zero signal, $R_{0}$, from the gross signal, $R$, and dividing by a factor $F$ :

$$
H_{\mathrm{P}}(d)=\frac{\left(R-R_{0}\right)}{F} .
$$

An algorithm which consists of a linear combination of the signal of multiple detectors can be used for multi-detector designs:

$$
H_{\mathrm{P}}(d)=\sum_{i=1}^{n} \frac{\left(R_{i}-R_{0, i}\right)}{F_{i}} .
$$

The algorithm can contain non-linear terms, such as raising the signal to a power:

$$
H_{\mathrm{P}}(d)=\sum_{i=1}^{n} \frac{\left(R_{i}-R_{0, i}\right)^{q_{i}}}{F_{i}} .
$$

In various algorithms the ratios of the signals are used in 'if then else' algorithms:

$$
\text { if } \begin{aligned}
\frac{R_{k}}{R_{l}}>r_{1} \text { then } H_{\mathrm{P}}(d) & =\sum_{i=1}^{n} \frac{\left(R_{i}-R_{0, i}\right)}{F_{i}}, \\
\text { else } H_{\mathrm{P}}(d) & =\sum_{i=1}^{n} \frac{\left(R_{i}-R_{0, i}\right)}{F_{i}^{\prime}} .
\end{aligned}
$$

In most cases the factors $F$ are (for each $i$ ) a combination of a factor determined during the type testing of the dosemeter, $f_{\mathrm{t}}$, a calibration factor $f_{\mathrm{c}}$ for the individual detectors and a factor, $f_{\mathrm{r}}$, accounting for the sensitivity of the reading equipment:

$$
F=f_{\mathrm{t}} f_{\mathrm{c}} f_{\mathrm{r}} .
$$

\section{Film dosemeters}

All dosimetric services that issue film dosemeters use an algorithm to calculate the operational quantity from the optical densities of multiple detectors. With the exception of one service, the algorithm used is a linear combination of the readings from the different detectors in the dosemeter or from the part of the film covered with different filters. As almost every dosemeter composition differs, the algorithms also differ from service to service. One service (PF5) reported the use of an algorithm where the photon energy is taken into account by the formula dose = $K$ (reading) $^{\mathrm{N}}$, where the values of parameters $K$ and $N$ depend on calibration and photon energy.

An example of the if-then algorithm, for the determination of $H_{\mathrm{P}}(0.07)$ and $H_{\mathrm{P}}(10)$ from the reading of film covered with different filters is given below:

For energy range, $20-1250 \mathrm{keV}$, $H_{\mathrm{P}}(0.07)=\left(K_{\text {air Sn/Pb }}+0.11 K_{\text {air } \mathrm{P} 300}-\right.$ $\left.0.1 K_{\text {air }} \mathrm{Cu} 300\right) \mathrm{Sv}$.

For energy range $<20 \mathrm{keV}$ (where $K_{\text {air }}$ P300 $/$ $\left.K_{\text {air } \mathrm{Cu} 300}>4\right), H_{\mathrm{P}}(0.07)=\left(0.4 K_{\text {air } \mathrm{Cu} 300}+\right.$ $\left.0.61 K_{\text {air P50 }}-0.6 K_{\text {air P300 }}\right) \mathrm{Sv}$.

Algorithm for calculation of $H_{P}(10)$ from the detector signals

For the energy range $20-1250 \mathrm{keV}, H_{\mathrm{P}}(10)=$ $\left(K_{\text {air } \mathrm{Sn} / \mathrm{Pb}}+0.11 K_{\text {air } \mathrm{P} 300}-0.1 K_{\text {air } \mathrm{Cu} 300}\right) \mathrm{Sv}$. For energy range $<20 \mathrm{keV}$ (where $K_{\text {air }}$ P300 $/$ $\left.K_{\text {air } \mathrm{Cu} 300}>4\right), H_{\mathrm{P}}(10)=\left(0.04 K_{\text {air P300 }}\right) \mathrm{Sv}$,

where:

$K_{\text {air Sn/Pb }}$ is apparent gamma ray air kerma under $440 \mathrm{mg} \mathrm{cm}^{-2} \mathrm{Sn}$ and $340 \mathrm{mg} \mathrm{cm}{ }^{-2} \mathrm{~Pb}$ filters.

$K_{\text {air P300 }}$ is apparent gamma ray air kerma under $300 \mathrm{mg} \mathrm{cm}^{-2}$ plastic filter.

$\mathrm{K}_{\text {air Cu300 }}$ is apparent gamma ray air kerma under $300 \mathrm{mg} \mathrm{cm}^{-2} \mathrm{Cu}$ filter.

$\mathrm{K}_{\text {air P50 }}$ is apparent gamma ray air kerma under $50 \mathrm{mg} \mathrm{cm}^{-2}$ plastic filter.

To subtract the density due to fogging, all services use a set of control dosemeters. In some cases the dosemeters used to determine the characteristic curve of the film also serve for this purpose. In that case all films are of the same batch, stored in normal laboratory environment and developed at the same time as the films of the dosemeters of the customers.

\section{Thermoluminescence dosemeters}

\section{Algorithms}

The different algorithms that are used to calculate the dose from the TLD-reader signal as reported by the services can be divided into three categories:

No algorithm used: The quantity is directly calculated from the signal from one of the detectors in the dosemeter by applying a sensitivity correction factor (Equation 1),

Algorithms using multiple detectors: A combination of the readings of different detectors is used to obtain the desired quantity (Equations 2 and 3), If-then algorithm: Depending on the ratio of different detectors, a different formula is used to calculate the quantity (Equation 4). 
Table 8. Algorithms (no algorithm, multiply algorithm and if-then algorithm) used to calculate $H_{P}(10)$ and $H_{P}(0.07)$ from the TLD-reader signal, as reported by the services.

\begin{tabular}{|c|c|c|c|c|c|c|c|}
\hline & & \multicolumn{3}{|c|}{$H_{\mathrm{P}}(10)$} & \multicolumn{3}{|c|}{$H_{\mathrm{P}}(0.07)$} \\
\hline & & No & Multiply & If-then & No & Multiply & If-then \\
\hline A & PT1 & & & & & & \\
\hline A & PT2 & & $\mathrm{x}$ & & & & \\
\hline A & PT3 & & $\mathrm{x}$ & & & & \\
\hline B & PT4 & & & $\mathrm{X}$ & & & \\
\hline B & PT5 & & & & & & \\
\hline BG & PT39 & & $\mathrm{x}$ & & & $\mathrm{X}$ & \\
\hline BG & PT40 & & $\mathrm{x}$ & & & & \\
\hline BG & PT41 & & $\mathrm{x}$ & & & & \\
\hline BG & PT42 & & $\mathrm{x}$ & & & & \\
\hline BG & PT43 & $\mathrm{x}$ & & & & $\mathrm{x}$ & \\
\hline $\mathrm{CH}$ & PT6 & $\mathrm{x}$ & & & & & \\
\hline $\mathrm{CH}$ & PT7 & $\mathrm{x}$ & & & & & \\
\hline $\mathrm{CH}$ & PT8 & & & $\mathrm{X}$ & & & \\
\hline $\mathrm{CH}$ & РT9 & & $x$ & & & & \\
\hline $\mathrm{CH}$ & PT10 & & & & & & \\
\hline $\mathrm{CZ}$ & PT44 & $\mathrm{x}$ & & & $\mathrm{x}$ & & \\
\hline $\mathrm{CZ}$ & PT45 & $\mathrm{x}$ & & & $\mathrm{x}$ & & \\
\hline $\mathrm{D}$ & PT11 & & & & & & \\
\hline DK & PT12 & $\mathrm{x}$ & & & & & \\
\hline DK & PT13 & $\mathrm{x}$ & & & & & \\
\hline $\mathrm{E}$ & PT14 & & & $\mathrm{x}$ & & & \\
\hline $\mathrm{E}$ & PT15 & & & & & & \\
\hline E & PT16 & & & & & & \\
\hline E & PT17 & & & $\mathrm{x}$ & & & \\
\hline EST & PT46 & $\mathrm{x}$ & & & & & \\
\hline FIN & PT19 & $\mathrm{x}$ & & & & & \\
\hline FIN & PT18 & & $\mathrm{x}$ & & & & \\
\hline HR & PT47 & & & & & & \\
\hline I & PT21 & $\mathrm{x}$ & & & $\mathrm{x}$ & & \\
\hline I & PT22 & $\mathrm{x}$ & & & & & \\
\hline I & PT32 & $\mathrm{x}$ & & & $\mathrm{x}$ & & \\
\hline I & PT33 & & & & & & \\
\hline I & PT34 & & & & & & \\
\hline I & PT35 & & & & & & \\
\hline I & PT36 & $\mathrm{x}$ & & & $\mathrm{x}$ & & \\
\hline I & PT37 & $\mathrm{x}$ & & & $\mathrm{x}$ & & \\
\hline I & PT38 & & & & & & \\
\hline IRL & PT20 & & $\mathrm{x}$ & & & & \\
\hline LT & PT49 & & $\mathrm{x}$ & & $\mathrm{x}$ & & \\
\hline $\mathrm{LT}$ & PT50 & $\mathrm{x}$ & & & $\mathrm{x}$ & & \\
\hline $\mathrm{LV}$ & PT48 & & & & & & \\
\hline NL & PT23 & $\mathrm{x}$ & & & & & \\
\hline NL & РT24 & & & $\mathrm{x}$ & & & \\
\hline NL & PT25 & & & & & & \\
\hline NL & PT26 & $\mathrm{x}$ & & & & & \\
\hline PL & PT51 & $\mathrm{x}$ & & & & $\mathrm{x}$ & \\
\hline PT & PT27 & $\mathrm{x}$ & & & & & \\
\hline RO & PT52 & $\mathrm{x}$ & & & $\mathrm{x}$ & & \\
\hline RO & PT53 & & $\mathrm{x}$ & & & & \\
\hline S & PT28 & $\mathrm{x}$ & & & & & \\
\hline S & РT29 & $\mathrm{x}$ & & & & & \\
\hline SI & PT54 & & $\mathrm{x}$ & & & & \\
\hline SI & PT55 & $\mathrm{x}$ & & & $\mathrm{x}$ & & \\
\hline SK & PT56 & $\mathrm{x}$ & & & $\mathrm{x}$ & & \\
\hline UA & PT57 & $\mathrm{x}$ & & & & & \\
\hline
\end{tabular}

Table 8. Continued

\begin{tabular}{|c|c|c|c|c|c|c|}
\hline & \multicolumn{3}{|c|}{$H_{\mathrm{P}}(10)$} & \multicolumn{3}{|c|}{$H_{\mathrm{P}}(0.07)$} \\
\hline & No & Multiply & If-then & No & Multiply & If-then \\
\hline UA PT58 & $\mathrm{x}$ & & & & & \\
\hline UK PT31 & & & & & & \\
\hline UK PT30 & $\mathrm{x}$ & & & & & \\
\hline YU PT59 & & & & & & \\
\hline YU PT60 & $\mathrm{x}$ & & & $\mathrm{x}$ & & \\
\hline
\end{tabular}

Most services determine the zero signal $R_{0}$ during the calibration of the reader, but glow curve analysis is also used.

In Table 8 the categories of algorithms used to calculate dose by services, are specified. Most services calculate $H_{\mathrm{P}}(d)$ without any special algorithm, by using an appropriate calibration factor, subtracting the background signal, sometimes applying correction for individual detector sensitivity and averaging the signal from 2-3 detectors.

\section{Background subtraction}

Dose due to natural background during the issuing period is usually below the detection limit of film dosemeters, therefore any background correction is seldom needed in these systems. If correction is needed, background control dosemeters are used.

The dosimetric services issue the correct TLDs for the dose due to the natural background radiation in three different ways: (i) no correction, (ii) control dosemeters and (iii) fixed national or regional averages. In Table 9 is summarised the information on the methods of subtraction of the natural background and the values applied, which are collected from the questionnaires. For 60 services, 35 use control dosemeters to assess the value of the background correction and 16 use the value of the national background. The subtracted values of natural background radiation vary between 0.4 and $2.4 \mathrm{mSv} \mathrm{y}^{-1}$.

\section{ENERGY AND ANGLE DEPENDENCY OF RESPONSE}

In the questionnaire, information on the response characteristics of the dosemeters was requested. The response is the quotient of the measured dose of radiation of specified energy and angle of incidence, and the true dose, $H_{\mathrm{P}}(d)_{\text {measured }} / H_{\mathrm{P}}(d)_{\text {true }}$. The true dose, $H_{\mathrm{P}}(d)_{\text {true }}$, is calculated from a measured dose rate, generally as air kerma free-in-air, using equipment traceable to a national (primary) standard, in conjunction with appropriate conversion coefficients $^{(7,9)}$.

Of the responding services, 32 gave sufficient information to show the energy dependence of the 
Table 9. Method of background subtraction and values in $\mathrm{mSv}^{-1}$

\begin{tabular}{|c|c|c|c|}
\hline Country & Service & Method & $\begin{array}{c}\text { Value } \\
\left(\mathrm{mSv} \mathrm{y}^{-1}\right)\end{array}$ \\
\hline
\end{tabular}

\begin{tabular}{lllllll}
\hline A & PT1 & No correction & UK & PT31 & \multicolumn{2}{c}{ Control dosemeters } \\
A & PT2 & No correction & YU & PT59 & & National average \\
A & PT3 & No correction & YU & PT60 & Na6 \\
\hline
\end{tabular}

National average

National average $\quad 0.88$

BG PT39

BG PT40

BG PT41

BG PT42

BG PT43

$\mathrm{CH} \quad \mathrm{PT} 10$

$\mathrm{CH} \quad \mathrm{PT} 6$

$\mathrm{CH} \quad \mathrm{PT} 7$

$\mathrm{CH} \quad \mathrm{PT} 8$

$\mathrm{CH} \quad \mathrm{PT} 9$

CZ $\quad$ PT44

CZ PT45

D PT11

DK PT12

DK PT13

E $\quad$ PT14

E PT15

E $\quad$ PT16

E $\quad$ PT17

EST PT46

FIN PT18

FIN PT19

HR PT47

I $\quad$ PT21

PT22

PT32

PT33

PT34

PT35

PT36

PT37

PT38

$\begin{array}{ll}\text { IRL } & \text { PT20 } \\ \text { LT } & \text { PT49 }\end{array}$

$\begin{array}{ll}\text { LT } & \text { PT49 } \\ \text { LT } & \text { PT50 }\end{array}$

$\begin{array}{ll}\text { LT } & \text { PT50 } \\ \text { LV } & \text { PT48 }\end{array}$

NL PT23

NL PT24

NL PT25

NL PT26

$\mathrm{P} \quad \mathrm{PT} 27$

PL PT51

RO PT52

RO PT53

S PT28

S PT29

SI PT54

SI PT55

SK PT56

UA PT57

UA PT58

UK PT30
Conional average

Control dosemeters

Control dosemeters

Control dosemeters

No correction

Control dosemeters

National average

National average

Control dosemeters

Control dosemeters

National average

Control dosemeters

Control dosemeters

National average

Control dosemeters

Control dosemeters

Control dosemeters

Control dosemeters

National average

Control dosemeters

National average

Control dosemeters

Control dosemeters

Control dosemeters

Control dosemeters

National average

Control dosemeters

Control dosemeters

Control dosemeters

Control dosemeters

Control dosemeters

Control dosemeters

National average

National average

Control dosemeters

Control dosemeters

National average

National average

Control dosemeters

No correction

Control dosemeters

National average

Control dosemeters

Control dosemeters

Control dosemeters

Control dosemeters

Control dosemeters

Control dosemeters

Control dosemeters

National average
Table 9. Continued

\begin{tabular}{llll}
\hline Country & Service & Method & $\begin{array}{c}\text { Value } \\
\left(\mathrm{mSv} \mathrm{y}^{-1}\right)\end{array}$ \\
\hline UK & PT31 & Control dosemeters & \\
YU & PT59 & National average & 0.96 \\
YU & PT60 & N & \\
\hline
\end{tabular}

response in graphical form. Only a few services gave information on the response at angles other than normal incidence.

The presented response curves are typically the results of type-test experiments in which the dosemeters are exposed to monochromatic or narrow spectrum radiation qualities, all at the same angle the case. In a number of dosemeters in which the detectors are far from tissue-equivalent there is strong reliance on algorithms that essentially attempt to estimate the quality of the radiation to which they were exposed. These systems may operate very successfully in monochromatic or narrow spectrum fields, but fail in mixed radiation situations. This can result in multi-detector dosemeters with very good response characteristics as judged from type tests, being, for specific practical situations, inferior to dosemeters with only one but approximately tissue-equivalent detector, which may show less favourable type-test response characteristics.

\section{Whole-body photon dosemeters}

0.8

$1.5-2.0$

0.6

$0.4-2.0$

1.46

0.6

1.6

0.66

0.8

0.77

0.66

1.7

1

$0.6-1.8$

$1.0-1.2$

$1.0-1.2$

$0.7-0.98$

0.6
Information on the energy dependency of the response of their film dosemeters was given by 10 services in terms of $H_{\mathrm{P}}(10)$, while 7 services provided data on response in terms of $H_{\mathrm{P}}(0.07)$. The information is shown in an anonymous form in Figures 4 and 5 .

Information on the energy response of TLDs was supplied by 26 dosimetric services. Information concerning $H_{\mathrm{P}}(10)$ is shown in anonymous form in Due to the flat energy response of TLDs for photon energy above $100 \mathrm{keV}$, the response of most TLDs fall within the plus and minus $20 \%$ limits. Only quite a few systems show larger deviations at energies below $100 \mathrm{keV}$.

\section{Whole-body beta dosemeters}

Information on the response characteristics of beta whole-body dosemeters was given by 15 dosimetric services. Five of these used film dosemeters and one service gave information on a direct ion storage dosemeter. Four services, using film dosemeters, reported response equal to 1.0 for all beta energies. In Figure 8 the data for nine beta TLDs are presented. Figure 6 and that concerning $H_{\mathrm{P}}(0.07)$ in Figure 7. of incidence. In practical situations, this is seldom 


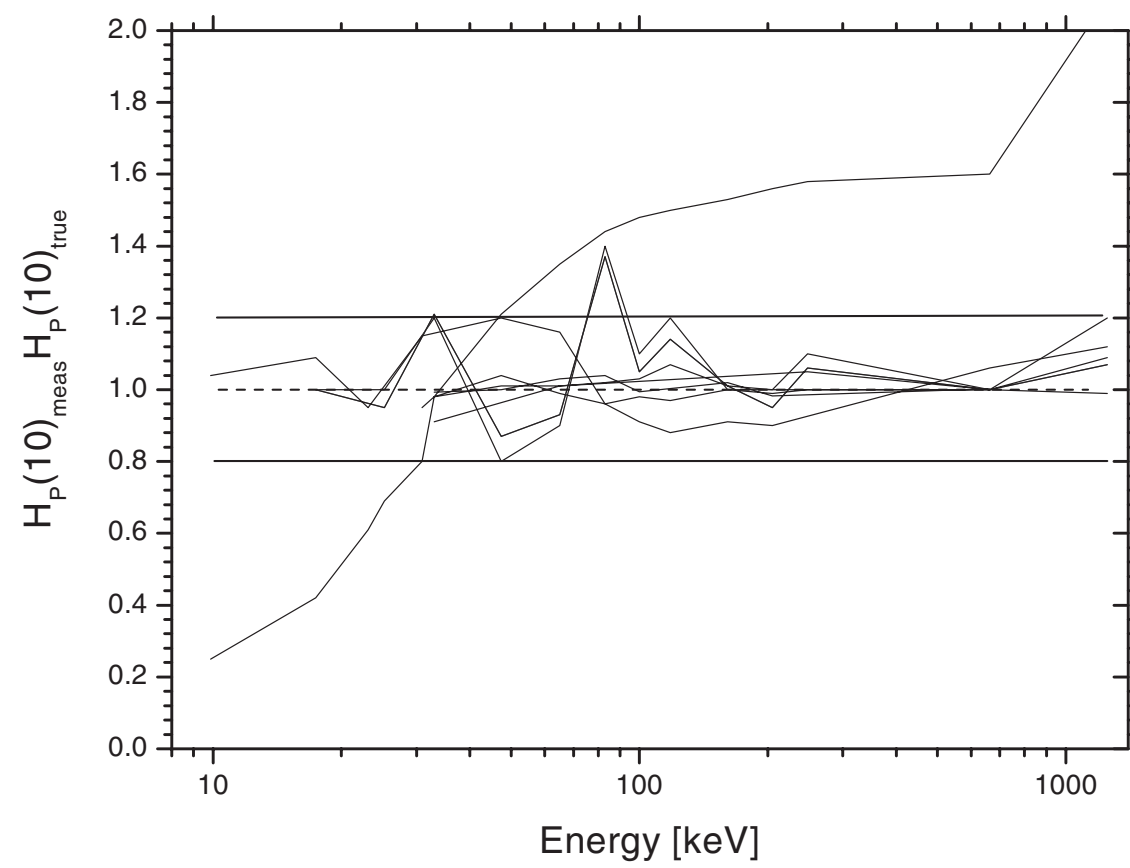

Figure 4. Response, $H_{\mathrm{P}}(10)_{\text {measured }} / H_{\mathrm{P}}(10)_{\text {true }}$ as a function of energy for whole-body photographic film photon dosemeters for normal incidence.

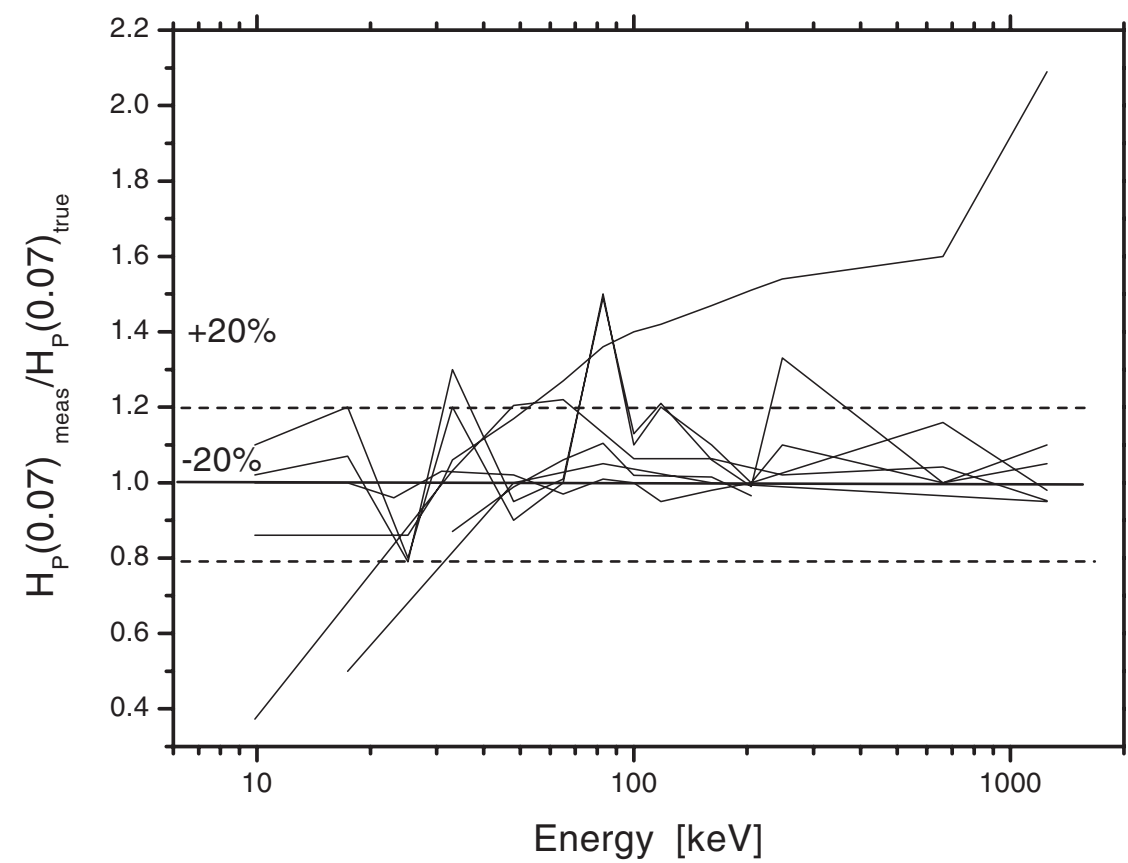

Figure 5. Response, $H_{\mathrm{P}}(0.07)_{\text {measured }} / H_{\mathrm{P}}(0.07)_{\text {true }}$ as a function of energy for whole-body photographic film photon dosemeters for normal incidence. 


\section{A. LOPEZ PONTE ET AL.}

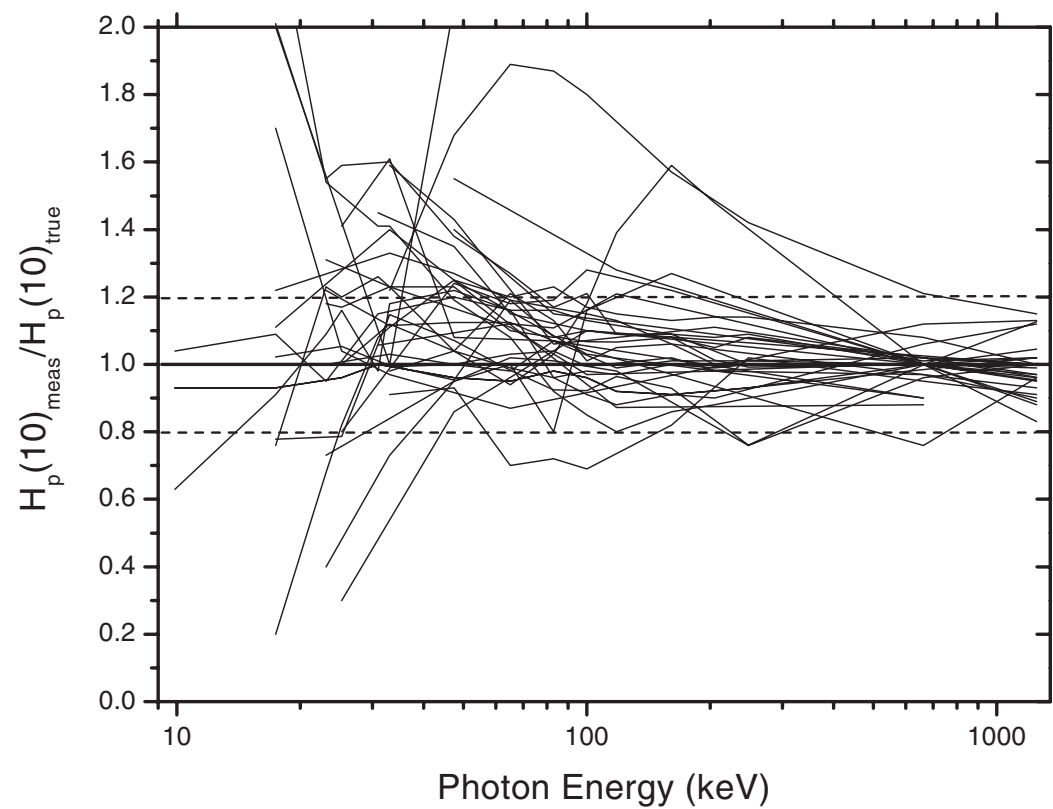

Figure 6. Response, $H_{\mathrm{P}}(10)_{\text {measured }} / H_{\mathrm{P}}(10)_{\text {true }}$ as a function of energy for whole-body photon TLDs for normal incidence.

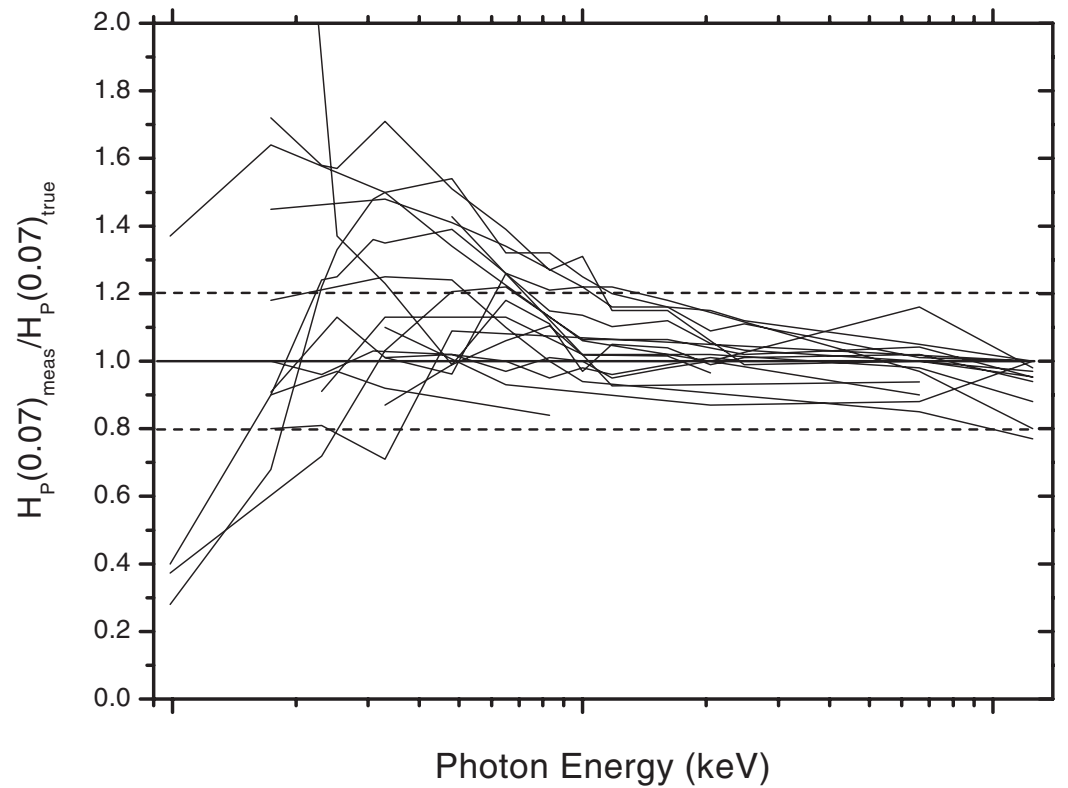

Figure 7. Response, $H_{\mathrm{P}}(0.07)_{\text {measured }} / H_{\mathrm{P}}(0.07)_{\text {true }}$ as a function of energy for whole-body photon TLDs for normal incidence.

\section{Whole-body neutron dosemeters}

Ten services gave information on the energy response of their neutron dosemeters. Figure 9 shows the response curves for these multi-element dosemeters
(NS and NM). As it is not feasible to generate neutrons in the energy range of roughly $10^{-7}$ to $10^{-2} \mathrm{MeV}$, no experimental data are available for that range. Therefore in this energy range, the calculated response for one system is shown. 


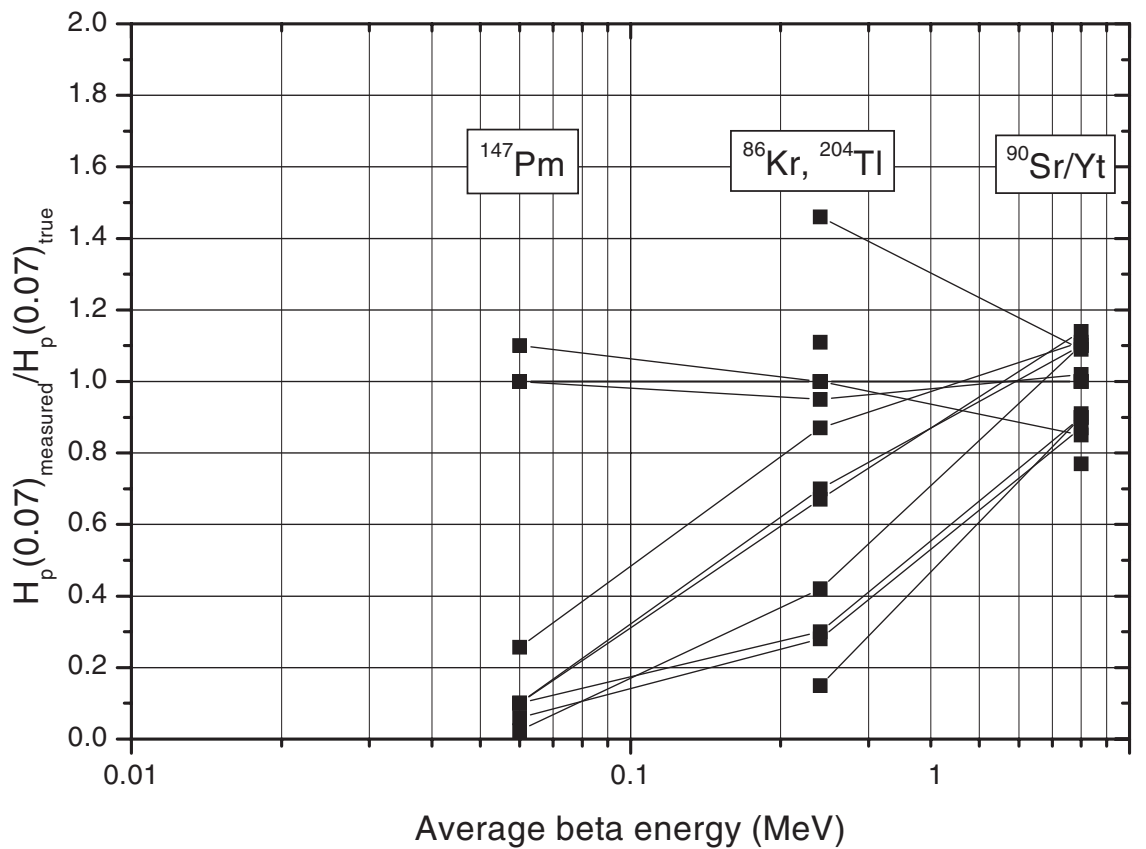

Figure 8. Response, $H_{\mathrm{P}}(0.07)_{\text {measured }} / H_{\mathrm{P}}(0.07)_{\text {true }}$ as a function of average beta energy (MeV) for whole-body beta TLDs at normal incidence.

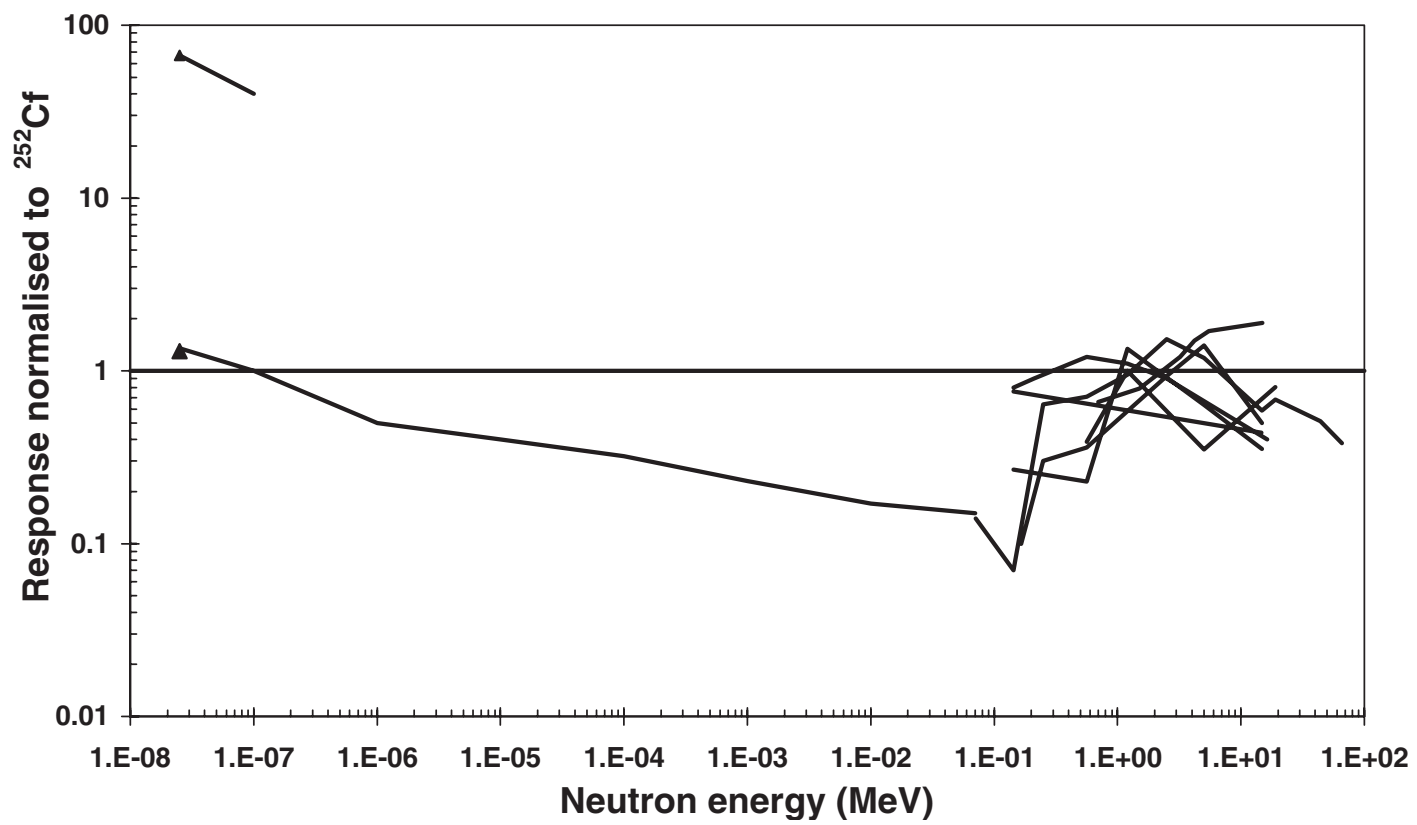

Figure 9. Response, $H_{\mathrm{P}}(10)_{\text {measured }} / H_{\mathrm{P}}(10)_{\text {true }}$ as a function of energy for multi-element (NS and NM) whole-body neutron dosemeters for normal incidence, normalised to ${ }^{252} \mathrm{Cf}$. 


\section{CALIBRATION}

The calibration procedure of the personal dosemeter relates the evaluated detector signal to the legal dosimetric quantity, e.g. $H_{\mathrm{P}}(d)$. The calibration process consists typically of two steps, i.e. (i) irradiation of the dosemeter in the reference field, with dose rate traceable to primary standards and performed typically on the relevant phantom and (ii) readout of the detector in the standardised conditions. The radiation field is frequently characterised in term of kerma in air rate, $K_{\text {air }}$, and $H_{\mathrm{P}}(d)$ is calculated using the conversion coefficients $H_{\mathrm{P}}(d) / K_{\mathrm{air}}{ }^{(7)}$ relevant for the given beam and phantom

In most cases the calibration factor $F$ is calculated as a combination of a factor determined during the type testing of the dosemeter, $f_{\mathrm{t}}$, a calibration factor $f_{\mathrm{c}}$ for the individual detectors and a factor, $f_{r}$, accounting for the sensitivity of the reading equipment (see 3.4).

The calibration procedures for different dosimetric systems, including film dosemeters and TLDs, are similar but some differences should be noted. One of them is that TLDs are typically re-used and therefore for most systems each detector can be characterised individually, by introducing individual calibration coefficients. A common practice is that these coefficients for the given batch of detectors are determined once a year, typically after $10-15$ readouts. For films, nuclear emulsions and track etch dosemeters no individual correction coefficients can be applied and typically only a batch homogeneity is checked.

The signal generated from the irradiated reference dosemeters at the output of the evaluating equipment have to be related to the value of dose. This signal is used to calibrate the entire evaluating system (e.g. TL reader), $f_{\mathrm{r}}$. However, the parameters of the system can show a short-term (within a single working day) and long-term instability. A full calibration in reference conditions is time consuming for every day operation of the dosimetric service. Therefore, for the daily check of stability of TLD-readers, simple ${ }^{90} \mathrm{Sr}-{ }^{90} \mathrm{Y}$ irradiators can be applied. The signal from detectors exposed by the irradiator should be related to the signal from detectors that underwent the full calibration performed in reference conditions (beam traceable to national standards, relevant phantom). After type testing of dosemeters on appropriate phantoms, the routine recalibration, which essentially is the determination of a sensitivity correction factor, can be done free-in-air. Of the services that use a phantom, about $50 \%$ use the ISO water filled slab, the others use the ICRU PMMA slab phantom. Most services use PMMA sheets for build-up.

Irradiation sources. For the actual calibration radioactive sources are used. Isotopes in general use are ${ }^{137} \mathrm{Cs}$ and ${ }^{60} \mathrm{Co}$. A few services report the use of
${ }^{90} \mathrm{Sr}-{ }^{90} \mathrm{Y}$ and ${ }^{226} \mathrm{Ra}$. Most services that responded to the section of the questionnaire on calibration report that their sources are traceable to a national (primary) standard.

Evaluating equipment. In many cases, the evaluating equipment, in particular TLD-readers, is tested and calibrated daily with reference dosemeters irradiated to a known dose. Some frequencies are reported for as low as once a year. Most services use ${ }^{137} \mathrm{Cs}$ sources for this routine calibration, but several others use ${ }^{60} \mathrm{Co}$ and ${ }^{90} \mathrm{Sr}-{ }^{90} \mathrm{Y}$ irradiators.

Dosemeters. Batches of photographic films are calibrated periodically, usually once per month or on arrival of a new consignment from the manufacturer, by taking representative samples.

Thermoluminescence dosemeters are in general recalibrated once a year or after a number of issuing periods that may also often be annually. For the radiation sources used the same applies as for the equipment calibration.

\section{PERFORMANCE}

Requirements for approval of a dosimetric service by the authorities always address the performance of the dosemeter and its evaluation system. These approval requirements can be very detailed, setting criteria for a great number of performance parameters, or set only limits to the overall uncertainty in a dose assessment. In general the international and national requirements for the performance of dosimetric systems are derived from ICRP and ICRU recommendations. In ICRP Publication 75 'General Principles for the Radiation Protection of Workers $^{(8)}$ the following is stated:

In practice, it is usually possible to achieve an accuracy of about $10 \%$ at the $95 \%$ confidence level for measurements of radiation fields in good laboratory conditions. In the workplace, where the energy spectrum and orientation of the radiation field are generally not well known, the uncertainties in a measurement made with an individual dosemeter will be significantly greater. Non-uniformity and uncertain orientation of the radiation field will introduce errors in the use of standard models. The overall uncertainty at the $95 \%$ confidence level in the estimation of effective dose around the relevant dose limit may well be a factor of 1.5 in either direction for photons and may be substantially greater for neutrons of uncertain energy, and for electrons. Greater uncertainties are also inevitable at low levels of effective dose for all qualities of radiation.

And further on: ... the recording level for individual monitoring should be derived from the duration of the monitoring period and an annual effective 
dose of no lower than $1 \mathrm{mSv} \ldots$ and ... 'the recording level is useful in defining the low dose requirements of dosemeters; it can be used as the basis for defining performance requirements'.

For the evaluation of the uncertainty in a dose assessment, e.g. using the procedures recommended in the ISO Guide for the Expression of Uncertainty in Measurements $(\mathrm{GUM})^{(10)}$, the asymmetrical confidence band given in ICRP $75^{(9)}$ is inconvenient. In the EU recommendations ${ }^{(11)}$, therefore, the uncertainty is given as a relative standard uncertainty of $0.21(21 \%)$. The interpretation in ICRU report $47^{(12)}$ states, 'in most cases, an overall uncertainty of one standard deviation of $30 \%$ should be acceptable' thus translating the range of $1 / 1.5$ to 1.5 as mentioned in ICRP 75 into a relative standard uncertainty of 0.30 .

All these confidence limits and uncertainties are in general interpreted as referring to the instrumental errors only. Thus inappropriate use of the dosemeter and very inhomogeneous fields where a single dosemeter can never provide a good estimate of total body exposure are conditions that are not considered in these discussions.

The performance can roughly be analysed in two ways: (1) A performance test where irradiation takes place in simulated workplace conditions and (2) a type test in which the characteristics of the dosemeters are assessed and the uncertainties evaluated from the test results.

\section{Performance test}

One method is irradiating an appropriate number of dosemeters to a variety of radiation fields and conditions of which the dose rates are known and traceable to national standards. These fields should preferably be representative of realistic workplace fields. If the number of dosemeters and the number of irradiation conditions is large and varied enough, then if $95 \%$ of the results lie within 0.667 times and 1.5 times the true value, it can be claimed that the dosemeter complies with the above-mentioned ICRP recommendations.

Such performance tests are, for example, organised by international organisations such as the IAEA ${ }^{(13)}$ and EURADOS ${ }^{(14)}$. In the results of the most recent EURADOS, intercomparisons are plotted and the irradiation conditions are summarised.

Figure 10 shows that for all but four irradiation conditions, all points (all but one in the case of PO11) fall within the range 0.667-1.5. The fields that some dosemeters seem to have a problem with are the $6 \mathrm{MeV}$ photons of PO2, PO3 and PO4. In field $\mathrm{PO} 2$, the $\mathrm{R}-\mathrm{F}$ radiation is mixed with $80 \%$ $300 \mathrm{keV}$ wide spectrum photons rotated at angles ranging from +80 to $-80^{\circ}$ (See Table 10). In field PO4, there was no electronic equilibrium, a condition for which the dosimetric quantities are not defined. The field PO12 also presents a problem, however, this is a low-dose field for which the

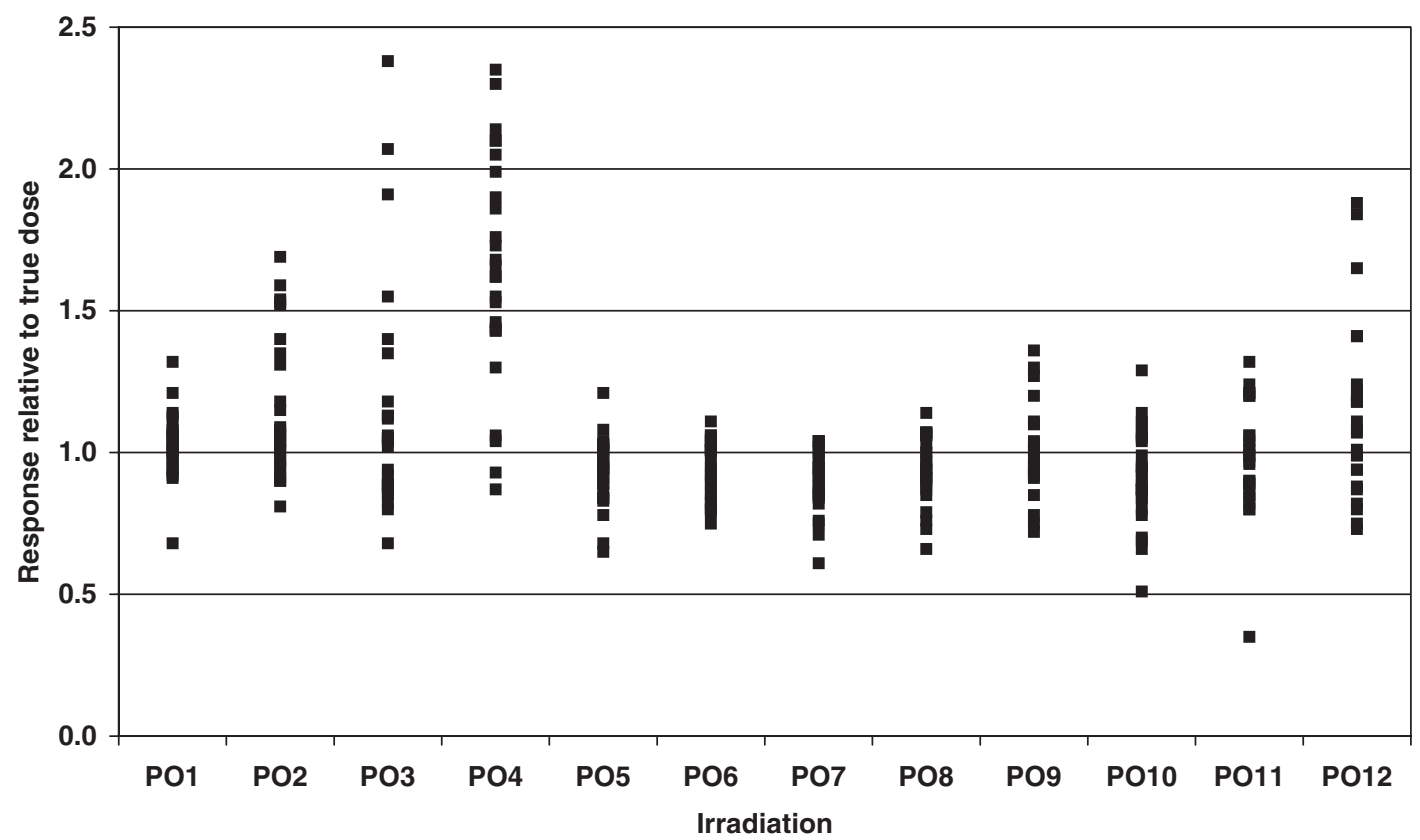

Figure 10. Results of the EURADOS intercomparison showing the response of 26 different dosemeter types for 12 irradiation conditions. 
M. A. LOPEZ PONTE ET AL

Table 10. Radiation qualities, angles of incidence and nominal dose values selected together with some additional information.

\begin{tabular}{lllc}
\hline $\begin{array}{l}\text { Radiation } \\
\text { field code }\end{array}$ & \multicolumn{1}{c}{ Radiation quality } & $\begin{array}{c}\text { Irradiation } \\
\text { laboratory }\end{array}$ & $\begin{array}{c}\text { Nominal } H_{\mathrm{P}}(10)_{\text {slab }} \\
\text { dose value }(\mathrm{m} \text { Sv) }\end{array}$ \\
\hline P1 & R-F $\left(0^{\circ}\right)+\mathrm{W}-300\left(\mathrm{WA} \pm 80^{\circ}\right)[50+50 \%]$ & PTB & 1.0 \\
P2 & R-F $\left(0^{\circ}\right)+\mathrm{W}-300\left(\mathrm{WA} \pm 80^{\circ}\right)[20+80 \%]$ & PTB & 7.2 \\
P3 & R-F $\left(0^{\circ}\right)$ & PTB & 1.0 \\
P4 & R-F $\left(0^{\circ}\right)$ without electronic equilibrium & PTB & 1.0 \\
P5 & S-Ir $\left(0^{\circ}\right)+$ S-Ir $\left(\mathrm{WA} \pm 80^{\circ}\right)[50+50 \%]$ & ARCS & 10 \\
P6 & S-Ir $\left(0^{\circ}\right)$ & ARCS & 1.0 \\
P7 & S-Ir $\left(0^{\circ}\right)$ & ARCS & 40 \\
P8 & S-Ir $\left(\mathrm{WA} \pm 80^{\circ}\right)$ & ARCS & 10 \\
P9 & S-Co $\left(0^{\circ}\right)+\mathrm{W}-80\left(\mathrm{WA} \pm 80^{\circ}\right)[50+50 \%]$ & NRPB & 3.0 \\
P10 & S-Co $\left(0^{\circ}\right)+\mathrm{W}-80\left(\mathrm{WA} \pm 80^{\circ}\right)[80+20 \%]$ & NRPB & 80 \\
P11 & S-Co $\left(0^{\circ}\right)+\mathrm{W}-80\left(\mathrm{WA} \pm 80^{\circ}\right)[80+20 \%]$ & NRPB & 1.0 \\
P12 & W-80 $\left(\mathrm{WA} \pm 80^{\circ}\right)$ & NRPB & 0.4 \\
\hline
\end{tabular}

Field codes as in ISO 4037 WA denote wide angle irradiations giving the angles of rotation and the percentages show the dose proportions for mixed fields.

ICRP recommends a wider range from 0.5 to 2 for the $95 \%$ confidence interval. Over all, excluding PO4, $94 \%$ of the measurements were within the $0.667-1.5$ range. Film dosemeters tend to have more problems with mixed fields than have TLDs, mainly because the detectors are much closer to being tissue-equivalent. Of the results from TLDs, $98 \%$ were within the recommended limits. The response curves of the participating dosemeters are among the curves shown in Figures 6 and 7.

\section{Type test}

Guidance for type testing of dosemeters can be found in the recommendations of the $\mathrm{EU}^{(11)}$, Safety Guides of the IAEA ${ }^{(15)}$ and International standards, such as ISO $1757^{(16)}$ for film dosemeters, IEC $61066^{(17)}$ for TLD and IEC $61283^{(18)}$ for electronic personal dosemeters (See Table 11). As an example, the results of type testing of three different TLD systems has been reported by Julius et al. ${ }^{(19)}$.

Major issues in the type test are determination of the energy and angular dependence of the response, the repeatability of a measurement and the detection and determination limits. Using the methods given in the $\mathrm{GUM}^{(10)}$ the combined results of such experiments can be used to estimate the combined standard uncertainty in a dose assessment. This combined standard uncertainty can than be compared with the recommendations mentioned earlier. If the recording level of $1 \mathrm{mSv}$ on an annual basis is interpreted as a detection limit, then it can be converted to a required detection limit on a monthly basis of about $\frac{1}{12}$ or $0.3 \mathrm{mSv}$ and thus a standard uncertainty of less than $0.1 \mathrm{mSv}$. It must be emphasised, however, that the notion of recording level, as coined in ICRP $75^{(9)}$ does not go together with the current concepts of quality assurance as recommended in international standards, such as ISO
$17025^{(20)}$. The recording level must only be used for deriving a requirement for the detection limit and certainly not as a recommendation to delete dose measurements from the databases.

The results of repeated measurements can be evaluated by standard deviations. The standard deviation of doses at the level of the natural background radiation can be used to determine the detection limit, as a rule-of-thumb, 3 times the standard deviation, and the limit of quantitative determination, roughly 10 times the standard deviation ${ }^{(21)}$. These limits can then be compared with the recording level, as discussed above. The variation in measurement results, as expressed by the standard deviation, is of course also a measure for the uncertainty in individual dose assessment. The ISO GUM ${ }^{(10)}$ assigns to the standard uncertainty the same numerical value of the standard deviation in what is called type-A evaluation of standard uncertainty.

The results of measurements of the response, the ratio of the measured dose and the true dose, as a function of radiation energy and as a function of angle of radiation incidence can be used to estimate the contribution of these factors to the overall uncertainty in a dose assessment. Using methods given in the ISO GUM ${ }^{(10)}$ and called type-B evaluation of standard uncertainty can then be used to convert these results to standard uncertainty. This evaluation requires presuppositions on the probability distribution of the influence parameters. If such a distribution is not known a rectangular distribution is considered in most cases, meaning that all responses found in the type test have equal probability. The corresponding standard uncertainties are then calculated as being the difference between the highest and lowest response divided by $2 / 3$.

Having thus the results of type-A and type-B evaluations for the various parameters, the combined 
Table 11. Statistics on the quality assurance programme of dosimetric services in Europe.

\begin{tabular}{|c|c|c|c|c|c|c|}
\hline $\begin{array}{l}\text { Country } \\
\text { Code }\end{array}$ & $\begin{array}{c}\text { 'Blind' } \\
\text { test }\end{array}$ & $\begin{array}{l}\text { ISO } \\
9000\end{array}$ & $\begin{array}{c}\text { EN } \\
45000\end{array}$ & GLP & $\begin{array}{c}\text { ISO } \\
17025\end{array}$ & Comments \\
\hline A & & & 4 & & & $\begin{array}{l}\text { All approved dosimetric services are subjected to a quality test } \\
\text { programme by the Federal Office of Metrology (BEV). }\end{array}$ \\
\hline B & & & & & & $\begin{array}{l}\text { None of the services indicated that a QA-programme was } \\
\text { implemented. }\end{array}$ \\
\hline BG & 5 & & & & & One QA programme of the department was reported. \\
\hline $\mathrm{CH}$ & 4 & 1 & 1 & & 2 & \\
\hline $\mathrm{CZ}$ & & 1 & & 1 & & $\begin{array}{l}\text { Every year verification by Czech Metrological Institute. } \\
\text { Own programme of the Institute. }\end{array}$ \\
\hline $\mathrm{D}$ & & & & & & $\begin{array}{l}\text { None of the services reported to have a QA-programme } \\
\text { implemented. However, approved dosimetric services in } \\
\text { Germany are subjected to a quality test programme by the } \\
\text { Physikalisch Technische Bundesanstaltt PTB }\end{array}$ \\
\hline DK & 3 & & & & & \\
\hline $\mathrm{E}$ & 1 & & 1 & & & \\
\hline EL & 1 & & & & 1 & $\begin{array}{l}\text { The service has applied for laboratory accreditation through the } \\
\text { National Accreditation Board (NAB) }\end{array}$ \\
\hline \multicolumn{7}{|r|}{ (1) } \\
\hline $\mathrm{F}$ & & 1 & 1 & 1 & & $\begin{array}{l}\text { Dosimetric services are subject to 'announced' performance tests } \\
\text { organised by the Office de Protection contre les Rayonnements } \\
\text { Ionisants (OPRI). }\end{array}$ \\
\hline FIN & 2 & & 1 & & & \\
\hline $\begin{array}{l}\mathrm{H} \\
\mathrm{HR}\end{array}$ & & 1 & & & 1 & \\
\hline I & & & & & & $\begin{array}{l}\text { Two dosimetric services that responded, both participate in the } \\
\text { voluntary QA-test programme 'Experts in Personal Dosimetry' } \\
\text { (EPD) by ENEA. }\end{array}$ \\
\hline \multicolumn{6}{|c|}{ (2) } & $\mathrm{L}$ \\
\hline $\begin{array}{l}\text { LT } \\
\text { LV }\end{array}$ & & & & 1 & & Local Quality Assurance programme. \\
\hline NL & 2 & 1 & & & & \\
\hline PL & & & 3 & & & $\begin{array}{l}\text { All services are accredited by the Polish Centre of Accreditation, } \\
\text { PCA. All services will adopt their procedures to IS_17-25 }\end{array}$ \\
\hline $\mathrm{P}$ & & & & & & \\
\hline $\mathrm{RO}$ & 1 & & 1 & 1 & & $\begin{array}{l}\text { NPP Cernavoda reported that its QA programme is based on } \\
\text { Canadian Standard for NPP }\end{array}$ \\
\hline $\mathrm{S}$ & 1 & & & & & \\
\hline SI & 2 & & & & & The procedures of one Laboratory follow IEC 1066 \\
\hline SK & & & & & & One service reported its own QA programme \\
\hline UK & 4 & 1 & & & & \\
\hline YU & & 1 & 1 & 1 & & One service reported ISO-900, EN-4500 and GLP \\
\hline
\end{tabular}

uncertainty is calculated by taking the square root of the sum of squares of the individual uncertainty components. Using this evaluation method on the data supplied by the 20 respondents to the questionnaire, which supplied sufficient information on their systems, it is found that for only one (film) system is the combined standard uncertainty significantly larger than that recommended.

\section{Comparing with requirements}

The above evaluation based on type-tests results in larger standard uncertainties than those estimated on the basis of performance studies, such as the EURADOS and IAEA intercomparisons. This indicates that the supposed uniform distribution is not realistic for circumstances encountered in practical workplace fields. Quite likely, a triangular or normal distribution of errors is more appropriate, in particular for the angular dependence of the response. If these evaluations are used for metrological purposes this does not pose a serious problem when used with the knowledge of background dose. However, if type-test results are to be used as input for an approval procedure, percentages can become very important. The various ways of 


\section{A. LOPEZ PONTE ET AL.}

setting criteria based on type-test results in national and international standards and recommendations reflects the complexity of the discussion in this field ${ }^{(16-22)}$.

\section{SUMMARY AND CONCLUSIONS}

The catalogue of dosemeters and dosimetric services within the EU Member States and Switzerland, which was issued by EURADOS in the year $2000^{(1)}$, has been updated and extended by information on dosimetric services in the new EU Member States and Bulgaria, Croatia, Romania, Serbia and Montenegro, and Ukraine. The total number of dosimetric services in these European countries is now estimated to be about 200. The present catalogue is based on information collected from 91 European dosimetric services, among which 34 questionnaires from 32 services were obtained over the years 2001-2004 for the first time. The new report reviews and updates the presently used designs of personal dosemeters and the extent to which occupationally exposed persons in Europe are monitored with dosemeters, which are able to measure the operational quantity-personal dose equivalent, $H_{\mathrm{P}}(d)$. The perspective of joining EU by the new countries has accelerated the implementation of the EU Basic Safety Standard Directive ${ }^{(2)}$ to their national regulations. As a result, all newly investigated services reported their ability to measure $H_{\mathrm{P}}(d)$. The catalogue provides updated information on the dosemeters, dose calculation and background subtraction algorithms, type-testing methods, energy and angular response and performance.

The main objective of the harmonisation of radiation protection systems within European states is to allow for the reliable comparison and transfer of dosimetric data for occupationally exposed people within Europe and in consequence, to facilitate mobility of radiation workers. A large number of dosimetric services in Europe, using a great variety of dosemeters with different types of detectors, makes this task difficult. A further harmonisation work is needed, oriented at periodical organisation of European intercomparisons of personal dosemeters that can be used for dosimetric services, which we wish to participate.

\section{REFERENCES}

1. van Dijk, J. W. E., Bordy, J. M., Vanhavere, T. F., Wernli, C. and Zamani-Valasiadou, M., A catalogue of dosemeters and dosimetric services within EU Member States and Switzerland able to estimate external radiation doses as personal dose equivalent. Radiat. Prot. Dosim. 89, (1-2), 53-105 (2000).

2. European Commission. Council Directive 96/29/ EURATOM of 13 May 1996 laying down basic safety standards for the protection of the health of workers and the general public against the dangers arising from ionizing radiation. Off. J. Eur. Commun. L159 39, (1996).

3. Bartlett, D. T. and Steele, J.D. Characteristics of personal dosemeters to measure $H_{\mathrm{P}}(10)$ for photons. In Intercomparison for Individual Monitoring of External Exposure from Photon Radiation, IAEA TECDOC 1126 (1999).

4. Christensen P., Herbaut Y. and Marshall T. O. Personal monitoring for external sources of beta and low energy radiations. Radiat. Prot. Dosim. 18, 241-260 (1987).

5. Bilski, P., Olko, P., Burgkhardt, B. and Piesch, E. Ultra-thin LiF: $\mathrm{Mg}, \mathrm{Cu}, P$ detectors for Beta Dosimetry, Radiat. Measur. 24, 439-443, (1995).

6. Bilski, P., Olko, P., Burgkhardt, B., Piesch, E. and Waligórski, M. P. R. Thermoluminescent efficiency of LiF: $M g, C u, P(M C P-N)$ detectors to photons, betaelectrons, alpha particles and thermal neutrons. Radiat. Prot. Dosim. 55, 31-38, (1994).

7. International Commission on Radiation Units and Measurements. Conversion coefficients for use in radiological protection against external radiation. ICRU Report 57, (Bethesda, MD: ICRU) (1998).

8. International Commission on Radiological Protection. General Principles for the Radiation Protection of Workers. ICRP Publication 75. Ann. ICRP 27 (1) (Oxford: Pergamon Press) (1997).

9. International Commission on Radiation Units and Measurements. Quantities and units in radiation protection dosimetry. ICRU Report 51 (Bethesda, MD: ICRU) (1997).

10. International Organization for Standardization. Guide to the expression of uncertainty in measurement. Supported by BIPM, IEC, IFCC, ISO, IUPAC, IUPAP and OIML, (Geneva: ISO) (1995).

11. Christensen, P., Julius, H. W. and Marshall, T. O. Radiation protection 73 , technical recommendations for monitoring individuals occupationally exposed to external radiation. EUR 14852 European Commission DGXI (Luxembourg: EC) (1994).

12. International Commission on Radiation Units and Measurements. Measurement of dose equivalents from external photon and electron radiations. ICRU Report 47, (Bethesda, MD: ICRU) (1992).

13. International Atomic Energy Agency. Intercomparison for individual monitoring of external exposure from photon radiation. IAEA-TECDOC-1126 (Vienna: IAEA) (1999).

14. Bordy, J. M., Stadtmann, H., Ambrosi, P., Bartlett, D. T., Christensen, P., Colgan, T. and Hyvonen, H., Performance test of dosimetric services in the EU Member States and Switzerland for the routine assessment of individual doses (photon, beta and neutron). Radiat. Prot. Dosim. 89, 107-154 (2000).

15. International Atomic Energy Agency. Assessment of occupational exposure due to external sources of radiation. IAEA Safety Standards Series No. RS-G-1.3 (Vienna: IAEA) (1999).

16. International Organization for Standardization. Personal photographic dosemeters. ISO 1757 (Geneva: ISO) (1996).

17. International Electrotechnical Commission. Thermoluminescent dosimetry systems for personal and 
environmental monitoring. IEC 61066 (Geneva: IEC) (1991).

18. International Electrotechnical Commission. Radiation protection instrumentation - direct reading personal dose equivalent (rate) monitors-X, gamma and high energy beta radiation. IEC 61283 (Geneva: IEC) (1995).

19. Julius, H. W., Marshall, T. O., Christensen, P. and VanDijk, J. W. E., Type testing personal dosemeters for photon energy and angular response. Radiat. Prot. Dosim. 54 (3-4), 273-277 (1994).

20. International Organization for Standardization. General requirements for the competence of testing and calibration laboratories. ISO/IEC 17025:2000, (Geneva: ISO) (2000).

21. Currie, L. A., Limits of qualitative detection and quantitative determination. Anal. Chem. 40 (3), 586-593 (1968).

22. American National Standards Institute. American national standard for dosimetry-personal dosimetry performance criteria for testing. ANSI/HPS 13.11:2001 Health Physics Society (2001).

\section{APPENDIX}

\section{List of Dosimetric Services in Europe, which Responded to the Questionnaire}

1. A Dosemeterservice Seibersdorf Austrian Research Centre Seibersdorf, Hannes Stadtmann, 2444 Seibersdorf, Austria, Tel: +43 2254780 2514, Fax: +43 2254780 2502, E-mail: hannes. stadtmann@arcs.ac.at

2. A Pruefstelle fuer Strahlenschutz PSS, Harald Spreizer, Auenbruggerplatz 32, A-8036 Graz, Austria, Tel: +43316385 2440, Fax: +43 316 3854147

3. A Gemeinsame Einrichtung fur Personendosimetrie, Dietmar Muller, Innrain 66, 6020 Insbruck, Austria, Tel: +43 512504 5780, Fax: +43512504 5729, E-mail: dietmar.mueller@, uklibk.ac.at

4. A Physikalisch Technische Prüfanstalt für Radiologie, Dr. Spreitzer, Wärwger Gurtel 18-20, A-1090 Vienna, Austria, Tel: +43 140400 6000, Fax +431404006030

5. B Radiation Protection Dept. University Ghent, H.M.A. Thierens, Proeftuinstraat 86, 9000 Ghent, Belgium, Tel: +32 92646643 or 54

6. B Dosimetry SCK-CEN, Filip Vanhavere, Boeretang 200, 2400 Mol, Belgium, Tel: +32 14 3328 80, Fax: 321432 1056, E-mail: fvanhave@, sckcen.be

7. B Radiotherapy UZ Gasthuisberg, J. van Dam, Herestraat 49, 3000 Louven, Belgium, Tel: +32 16347642

8. BG Kozloduy NPP, Kozloduy Nuclear Power Plant-Personnel Dosimetry, Maria Neshkova, Kozloduy NPP - PLC, 3321 Kozloduy, Bulgaria,
Tel: ++359973 72538, E-mail: mneshkova@, npp.cit.bg

9. BG Operational Radiation Dosimetry Control Service Radioactive Wastes Treatment Plant (RAWTP)(Kozloduy NPP), G. Dimov, Radioactive Wastes Treatment Plant (RAWTP), 3321 Kozloduy, Bulgaria, Tel: + 3599737 3027, E-mail: dimov@npp.cit.bg

10. BG Laboratories Protecta Laboratories Protecta Ltd., M.G. Gelev, 22 Ivan Vazov St., 1000 Sofia, Bulgaria, Tel: +359 98 384254, E-mail: MGelev@ yahoo.com

11. BG Laboratory for Radiation Protection (LRPINRNE) Institute for Nuclear Research and Nuclear Energy, M.G. Gelev, 72 Tzarigradsko chaussee blvd, 1784 Sofia, Bulgaria, Tel: +3592 7144 358, Fax: +3592975 3619, E-mail: mguelev@ inrne.bas.bg

12. BG NCRRP Nat Centre of Radiobiology and Radiation Protection Lab-Dosimetry of External Radiation, A.G. Karadjov, 132 Kliment Ohridski Blvd, 1756 Sofia, Bulgaria, Tel: +359 2 623214, Fax: +359 2 621059, E-mail: ncrrp@ncrrp.org

13. CH BKW FMB Energie AG, Markus Zuercher, ZUM, 3203 Muehleberg, Switzerland, Tel: +41 3175471 11, Fax: 413175471 23, E-mail: markuszuercher@swissonline.ch

14. CH Service de Dosimetrie Individuelle CERN, Otto Thomas, NS Division, 1211 Geneva, Switzerland, Tel: +41 2276721 55, E-mail: thomas.otto@cern.ch

15. CH Comet Technik AG, David Maurer, Stationsstrasse 12, 3097 Liebefeld, Switzerland, Tel: +41 31970 4463, Fax: +41 31970 4564, E-mail: ct.zurbrugg@bluewin.ch

16. $\mathrm{CH}$ Institut de radiophysique appliquee, A. Besancon, 1015 Lausanne, Switzerland, Tel: +41216933165

17. CH Division for Radiation Protection and Waste Management Paul Scherrer Institute PSI, Markus Boschung, 5232 Villigen, Switzerland, Tel: +41 56310 2111, E-mail: markus. boschung@psi.ch

18. $\mathrm{CH}$ Messtelle fuer Personendosimetrie PEDOS AG, B.S. Beat Steck, Unterer Wehrliweg 7B, 3074 Muri bei Bern, Switzerland, Tel: +41 31 9541313

19. CZ Temelin NPP Personal Dosimetry ServiceTemelin NPP, Martin Schacherl, CEZ, a.s., Divize Výstavba-jete, 37305 Temelín, Czech Republic, Tel: +420334783540, Fax: +4203342794, E-mail: schacm1.ete@mail.cez.cz

20. CZ Personal Dosimetry Department CEZ a.s NPP Dukovany, Zdenek Zelenka, 67550 Dukovany, Czech Republic, Tel: +420 618 813779, Fax: +420 618 866360, E-mail: zelenz1. edu@mail.cez.cz 


\section{A. LOPEZ PONTE ET AL.}

21. CZ NRI Rez Thermolluminescent Dosimetry NRI Rez, Milos Vidra, Husinec- Rez 130, 25063 Rez/ Praha, Czech Republic, Tel: +420 266173671, Fax: +4202 20940500, E-mail: vid@nri.cz

22. CZ IRP National Personal Dsoimetry Service, Jaroslav Trousil, Na Truhlarce 39/64, 18084 Praha, Czech Republic, Tel: +4202 84840400-1, Fax: +4202 8484040 0, E-mail: csod@iol.cz

23. D Auswertungsstelle fuer Strahlendosemeter AWS, J. Davis, Ingoldstaetter Landstrasse 1, 85761 Unterschleißheim, Germany, Tel: +49 8931872220

24. D HS/Messstelle Forschungszentrum Karlsruhe, Bertram Burgkhardt, Herman-von-Helmholtzplatz 1, D-76344 Eggenstein-Leopoldshaven, Germany, Tel: +49 724782 2082, Fax: +49 724782 2054, E-mail: burgkhardt@hs.fzk.de

25. D Materialprufungsambt NRW, Frank Busch, Marsbruchstr. 186, D 44285 Dortmund, Germany, Tel: +49 2314502 514, E-mail: frank. busch@physik.uni-dortmund.de

26. D Messstelle fuer Strahlenschutz, Kar-Heinz Anger, Max-Brauer-Allee 134, 22765, Germany, Tel: +49 40 38073128, Fax +494042811-3273 E-mail: karl-heinz.anger@bug.hamburg.de

27. DK Laboratory for Personal Dosimetry and Medical Physics AKH, K.A. Jessen, Norrebrogade 44, 8000 Arhus, Denmark, Tel: +45 8949 2486, E-mail: kaj@medfysik.aau.dk

28. DK National Institute of Radiation Hygiene, Jens Munk, 378 Frederikssundsvey, 2700, Denmark, Tel: +45 4489 9119, Fax: +45 4453 2773, E-mail: jm@sis.dk

29. DK Personal Dosimetry Service RISO, P Christensen, Frederiksborgvej 399, 4140 Riso, Denmark, Tel: +45 46774914

30. EL Physics Department Aristotle University of Tessaloniki, M Zamani-Valasiadou, Tessaloniki, Greece, Tel: +30 31 998176, E-mail: zamani@ paros.physics.auth.gr

31. EL Greek Atomic Energy Commission, V. Kamenopoulou, 153 10, Greece, Tel: +30165 11360

32. ES Approved Dosimetry Service BNFL Chapelcross, R.H. Millard, DG12 6RF Annan, Dumfriesshire, Scotland, Tel: +44 1461202835

33. ES Centro de Dosimetria S.L., J Gultresa, Muntaner 447 bajos, 8021 Barcelona, Spain, Tel: +34 32013495

34. ES Centro Nacional de Dosimetria, E. Casal, Avda. Campanar 21, PO Box 46009 Valenzia, Spain, Tel: +34 9634979 22, E-mail: emilio. casal@uv.es

35. ES CIEMAT, J.C. Saez Vergara, Av. Complutense 22 (Ed. 7), 28040 Madrid, Spain, Tel: $+3413466253$
36. ES Servicio de Radioproteccion Centro Nacional de Sanidad Ambiental, C. Ruiz, 28220 Madrid, Spain, Tel: +34 150979 84, E-mail: cruiz@, isciii.es

37. EST ERPC Estonian Radiation Protection Centre, Kiira Kornysheva, Kopli str. 76, 10416 Tallinn, Estonia, Tel: +372 660 3336, Fax: +372 660 3352, E-mail: ekk@ekk.envir.ee

38. F IPSN-DPEA-SEC Institut de Protection e de Sureté Nucléaire, Yvon Magry, F-92265 CE Fontenay-aux-Roses BP 63, France, Tel: +331 46547508

39. F Laboratoire Central des Industries Electriques LCiE, Guy Le Roy, 33 Avenue de General Leclerc, 92260 Fontenay-Aux-Roses, France, Tel: +331409562 90, Fax: +331 40956289

40. F Laboratoire de Dosimetrie et de Metrologie des Rayonnements - Cogema MarcouleSPR/CR/DMR CEDEX, M Espagnan, BP 170, 30206 Bagnol-sur-Ceze, France, Tel: +33 4 66795321

41. F OPRI, A. Biau, 31 Rue de l'Ecluse, 78116 Le Vessinet CEDEX, France, Tel: +33 13015 5200

42. F Division dosimetrie Philips Systemes Medicaux SAS, P. Pellissier / D. Jaegle, Route d'Ergnies, 80690 Ailly le Haut Clocher, France, Tel: +33 322 280 016, Fax: +33 32228084, E-mail: dominique. jaegle@brill.philips.com

43. F Service de prevention et de radioprotection, Jaques Kalimbadjian, Cogema/La Hague, 50444 Beaumont-Hague, France, Tel:+33 2 33026000, Fax: + 33233026205

44. FIN Loviisa powerplan (IVO) Imatran Voima Oy, Esko Hytonen, 07901 Lovisa, Finland, Tel: +35 819 5501, Fax: 358 195504435, E-mail: Esko.hytonen@ivo.fi

45. FIN Personal Dosimetry STUK, Radiation and Nuclear Safety Authority, Hannu Hyvoenen, Laippatie 4, 00881 Helsinki, Finland, Tel: +358 9 759881, Fax: 3589 75988248, E-mail: hannu. hyvonen@stuk.fi

46. HR RBI Ruð̈er Boŝkovi Institute, Branko Veki, Bijenicka cesta 54 PO Box 180, 10000 Zagreb, Croatia, Tel: +385 1 4561111, Fax: +385 1 4680084, E-mail: bvekic@rudjer.irb.hr

47. HR Ekoteh Dosimetry Co. Rad Protection Service, Mladen Novakobi, Vladimira Ruzdjaka 21, 10000 Zagreb, Croatia, Tel: +385 1604 3882, Fax: +3851604 3883, E-mail: ekoteh@zg.tel.hr

48. I C.I.R. s.a.s. Centro Italiano de Radioprotezione, Anna Ialenti, Via Filippo Chiappini n. 15, 00153 Roma, Italy, Tel: +39 65880495

49. I Institute for Radiation Protection ENEA, Elena Fantuzzi, Via dei Colli 16, 40136 Bologna, Italy, Tel: +3951 6098349

50. I Servizio di Fisica Sanitaria-Ospedale Maggiore, Gabriella Raimondi, via Pace 9, 20122 
Milano, Italy, Tel: +3902 55035223, Fax: +3902 55035100, E-mail: rai@policlinico.mi.it

51. I Servizio di Fisica Sanitaria Spedali Civili di Brescia, Piero Feroldi, Piazzale Spedali Civili, 1, 25100 BRESCIA, Italy, Tel: +39 030 3995284, Fax: + 39030 3995075, E-mail: fisicasan. bs@numerica.it

52. I Laboratorio di dosimetria personale ed ambientale Istituto Nazionale per lo studio e la cura dei Tumori, Marta Borroni, Via Venezian 1, 20133 Milano, Italy, Tel: +39 223902309, Fax: +39 223902124, E-mail: filmdos@istitutotumori.mi.it

53. I X - Gammaguard, Vincenzo De Iorio, Via Gorizia, 40, 21047 SARONNO, Italy, Tel: +39 296702029, Fax: +39 29625945, E-mail: xg.guard@xgammaguard.it

54. I Fisica Sanitaria-ASL n.9 della RegioneVeneto, Lino Mantovani, Piazza Ospedale, 1, 31100 Treviso, Italy, Tel: +39 422 322278, Fax: +39 0422 322249, E-mail: Lmantovani@ulss.tv.it

55. I Health and Medical Physic Department Bufalini Hospital, Simonetta Lazari, Via Ghirotti, 286, 47023 Cesena, Italy, Tel: +39 0547 352682, Fax: +39 0547 302754, E-mail: fis.san@ausl-cesena.emr.it

56. I Umberto I Hospital Medical Physics Department, Lidia Angelini, Via Conca, 1, 60020 ANCONA, Italy, Tel: +39071 5964799, Fax:+39071 5964897

57. IRL Radiological Protection Institute of Ireland, Tony Colgan, 3 Clonskeagh Square, 14 Dublin, Ireland, Tel: +353 126977 66, E-mail: Tony@ rpii.ie

58. L Division de la Radioprotection, Nico Harpes, Villa Louvigny- Allée Marconi, L 2120 Louxembourg, Luxembourg, Tel: +352 4785673, Fax: +352 467521, E-mail: nico.harpes@ms.etat.lu

59. LT Ignalina NPP Ignalina Nuclear Power Plant, Victor Pletniov, LT-4761 Visaginas, Lithuania, Tel: +3706628828, Fax: +3706629350, E-mail: pletnev@mail.iae.lt

60. LT RPC Radiation Protection Centre, Gendrutis Morkunas, Kalvariju 153, LT- 2055 Vilnius, Lithuania, Tel: +370 2 763633, Fax: +370 2 754692, E-mail: rsc@rsc.lt

61. LV RDC Radiation Safety Centre, Konstantins Bogucarskis, 165 Maskavas str., LV-1019 Riga, Latvia, Tel: +371 2 7032691, Fax: +371 2 7032659, E-mail: k.bogucarskis@rdc.gov.lv

62. NL Dosimetry Services Nuclear Research and Consultancy Group (NRG), F.S. Draaisma, Westerduinweg 3, $1755 \mathrm{ZG}$, The Netherlands, Tel:+31 22456 4228, E-mail: draaisma@ecn.nl

63. NL Persoonsdosimetriedienst Vrije Universiteit en VU ziekenhuis, P.H. Dignum, van der Boechorststraat 1, 1081 BT, The Netherlands, Tel: +31 2044490 40, E-mail: ph.dignum@ dienst.vu.nl
64. NL Philips Stralingsbeschermingsdienst (P-SBD), L.T.M. Ebben, Willemstraat 22a, 5600 MD, The Netherlands, Tel: +31 402756300

65. NL NRG Radiation \& Environment, Janwillem E. van Dijk, Utrechtseweg 310, 6800 ES, The Netherlands, Tel: +31 263563084

66. PL CLOR Central Laboratory for Radiological Protection, H. Dzikiewicz-Sapiecha, Konwaliowa 7, PL-03-194 Warszawa, Poland, Tel: (48-22) 811 0011, Fax: (48-22) 811 1616, E-mail: hannads@ clor.waw.pl

67. PL IMP Nofer Institute of Occupational Medicine-Rad. Prot.Department, Jerzy Jankowski, Sw. Teresy 8, PO Box 199, 90-950 Lodz, Poland, Tel: +48 (42) 6314 549, Fax: +48 (42) 6314 548, E-mail: jjan@imp.lodz.pl

68. PL LADIS Institute of Nuclear Physics, Maciej Budzanowski, Radzikowskiego 152, PL 31-349 Krakow, Poland, Tel: +4812 6628457, Fax: +4812 6628066, E-mail: Maciej.Budzanowski@ ifj.edu.pl

69. PT ITN-DPRSN, Antonio Ferro de Carvalho, Estrada Naciomal 10, 2686-953 Sacavém, Portugal, Tel: +351 1955 0021, Fax: +351 1994 1995, E-mail: afferoc@intl.itn.pt

70. RO CEPIEM, R. Vasilache, 25, Pop de Basesti 59, sector2, Bucharest, Romania, Tel: +40 21252 42 23, Tele and Fax: +40 2125242 23, E-mail: 1milea@ cepiem.ro

71. RO DOZIMED, R. Vasilache, 25, Grigore Tocilescu St., PO Box 69 - 160, 7000 Bucharest, Romania, Tel: +40 21423 3259, Fax: +40 21423 3259, E-mail: dozimed@pcnet.ro

72. RO Film Detectors Survey Unit, Constantin Milu, Magurele PO Box MG 6, 76900 Bucharest, Romania, Tel: +40 14042300/4706, Fax: 40 14574432, E-mail: fmihai@ifin.nipne.ro

73. RO ELSD Environmental and Life Sciences Department, Constantin Milu, Magurele PO Box MG 7, R-76900 Bucharest, Romania, Tel: +401 4042300, Fax: +401 4574440, E-mail: stoc@ifin.nipne.ro

74. RO IRML Individual Radiation Monitoring Lab Ministry of Health and Family, Constantin Milu, Dr. Leonte No. 1-3, RO-76256 Bucharest, Romania, Tel: +40 21224 9245, Fax: +40 21224 9245, E-mail: cmilu@ispb.ro

75. RO Health Physics Laboratory CNE-PROD CERNAVODA, Mitica Baraitaru, Medgidiei No 1, 8625 Cernavoda, Romania, Tel: 40-41239-340 (ext. 1865), Fax: 40-41-239-679, E-mail: mbaraitaru@cne.ro

76. S Ringhals Dosimetrie, Per Drake, Vattenfall AB, 43022 Varovbacka, Sweden, Tel: +46 340 667151

77. S Swedish Radiation Protection Institute, Lennart Lindborg, Sweden, Tel: +46 872971 08, E-mail: lennart.lindborg@ssi.se. As from 
April 1999 the dosimetric service is operated by Studsvik Instrument AB

78. SI Krsko NPP Krsko NPP, Radiation Protection-Dosimetry Laboratory, Borut Breznik, Vrbina 12, SI-8270 Krško, Slovenia, Tel: +386 74802 00, Fax: +386 74921 006, E-mail: borut.breznik@nek.si

79. SI IOS Institute of Occupational Safety, Urban Zdesar.

80. SK Radiation Protection Department Bohunice NPP, Dobis Lubomir, 91931 Jaslovské Bohunice, Slovakia, Tel: ++421 33579 2128, Fax: ++421 335974786

81. UA CLRHMS Central Lab for rad hygiene of medical staff of Ukraine- S.Grigoriev Institute, L. Stadnyk, 82 Pushkin, 61024 Kharkiv, Ukraine, Tel: +380 5724371 20, Fax: +380 572 4371 20, E-mail: imr@online.kharkiv.com

82. UA ATS Radiation Protection Institute ATS Ukraine, V. Chumak, Melnikova 53, $4050 \mathrm{Kiev,}$ Ukraine, Tel: +380 4421934 14, Fax: +380 44 21934 14. E-mail: chumak@leed1.kiev.ua

83. UK BNFL Sellafield Dosimetry Service, NJ Parkes, B423, CA20 1PG Seascale, Cumbria, United Kingdom, Tel: +44 1946774 210, Fax: 441946771752

84. UK Dungeness B Dosimetry Service Nuclear Electric Ltd, J.M. Cheese, TN29 9PX Romney Marsh Kent, United Kingdom, Tel: +44 179734 34 78, Fax: +44 1797343001
85. UK Integrated Radiological Services Ltd, M. Lewis, Unit 188 Tower Street, L3 4BJ Liverpool, United Kingdom, Tel: +44 151709 6296

86. UK National Radiological Protection Board, P.J. Gilvin, OX11 0RQ Chilton Didcot, Oxon, United Kingdom, Tel: + 44123583 1600, Fax: 44123582 28 23, E-mail: phil.gilvin@nrpb.org.uk

87. UK NNC Ltd, Julie Clark, Booths Hall, Chelford Road, WA16 8QZ Knutsford GBCheshire, United Kingdom, Tel: +44 156584 3057

88. UK RPS Cardiff Radiation Protection Service, W. Thomas, Velindre NHS Trust, CF 4 7XL Cardiff, United Kingdom, Tel: +44 1222619 888 (ext. 6273), Fax: 441222522 694, E-mail: rps.cardiff@veundre-tr.wales.nhs.uk

89. YU Laboratory of Radiation and Environmental Protection Institute of Nuclear Sciences Vinca, Mirjana Prokic, M.Alasa 12-14, Vinca, PO Box 522, 11000 Belgrade, Serbia and Montenegro, Tel: +381 11453 867, Fax: +381 11455943

90. YU Institute of Occupational and Radiological Health Institute of Occupational and Radiological Health Dr Dragomir Karajovic, Olivera Marinkovic, Deligradska 29, 11000 Belgrade, Serbia and Montenegro, Tel: +381113618703, Fax: ++38111643675, E-mail: Rasa98@ptt.yu 